JULIANA CRISTINA MARINHEIRO

\title{
VARIABILIDADE GENÉTICA DE ADENOVÍRUS HUMANO DA ESPÉCIE B, ASSOCIADOS A CASOS \\ DE INFECÇÃO RESPIRATÓRIA AGUDA, EM SÃO PAULO, DE 1995 A 2006
}

Tese apresentada ao Instituto de Ciências Biomédicas da Universidade de São Paulo, para obtenção do Título de Doutor em Ciências (Microbiologia). 
JULIANA CRISTINA MARINHEIRO

\section{VARIABILIDADE GENÉTICA DE ADENOVÍRUS HUMANO DA ESPÉCIE B, ASSOCIADOS A CASOS DE INFECÇÃO RESPIRATÓRIA AGUDA, EM SÃO PAULO, DE 1995 A 2006}

Tese apresentada ao Instituto de Ciências Biomédicas da Universidade de São Paulo, para obtenção do Título de Doutor em Ciências.

Área de concentração: Microbiologia.

Orientadora: Profa. Dra. Charlotte Marianna Hársi

São Paulo 
DADOS DE CATALOGAÇÃO NA PUBLICAÇÃO (CIP)

Serviço de Biblioteca e Informação Biomédica do Instituto de Ciências Biomédicas da Universidade de São Paulo

reprodução não autorizada pelo autor

Marinheiro, Juliana Cristina.

Variabilidade genética de adenovírus humano da espécie B, associados a casos de infecção respiratória aguda, em São Paulo, de 1995 a 2006 / Juliana Cristina Marinheiro. -- São Paulo, 2009.

Orientador: Charlotte Marianna Harsi.

Tese (Doutorado) - Universidade de São Paulo. Instituto de Ciências Biomédicas. Departamento de Microbiologia. Área de concentração: Microbiologia. Linha de pesquisa: Virologia.

Versão do título para o inglês: Genetic variability of human adenovirus species B associated to acute respiratory infection, in São Paulo, from 1995 to 2006.

$\begin{array}{lll}\text { Descritores: } 1 \text {. Adenovírus humano } & \text { 2. Variabalidade genética }\end{array}$ Infecção respiratória 4. Filogenia 5. Reação de sequenciamento 6 . Região E3 I. Harsi, Charlotte Marianna II. Universidade de São Paulo. Instituto de Ciências Biomédicas. Programa de Pós-Graduação em Microbiologia III. Título. 
UNIVERSIDADE DE SÃO PAULO

INSTITUTO DE CIÊNCIAS BIOMÉDICAS

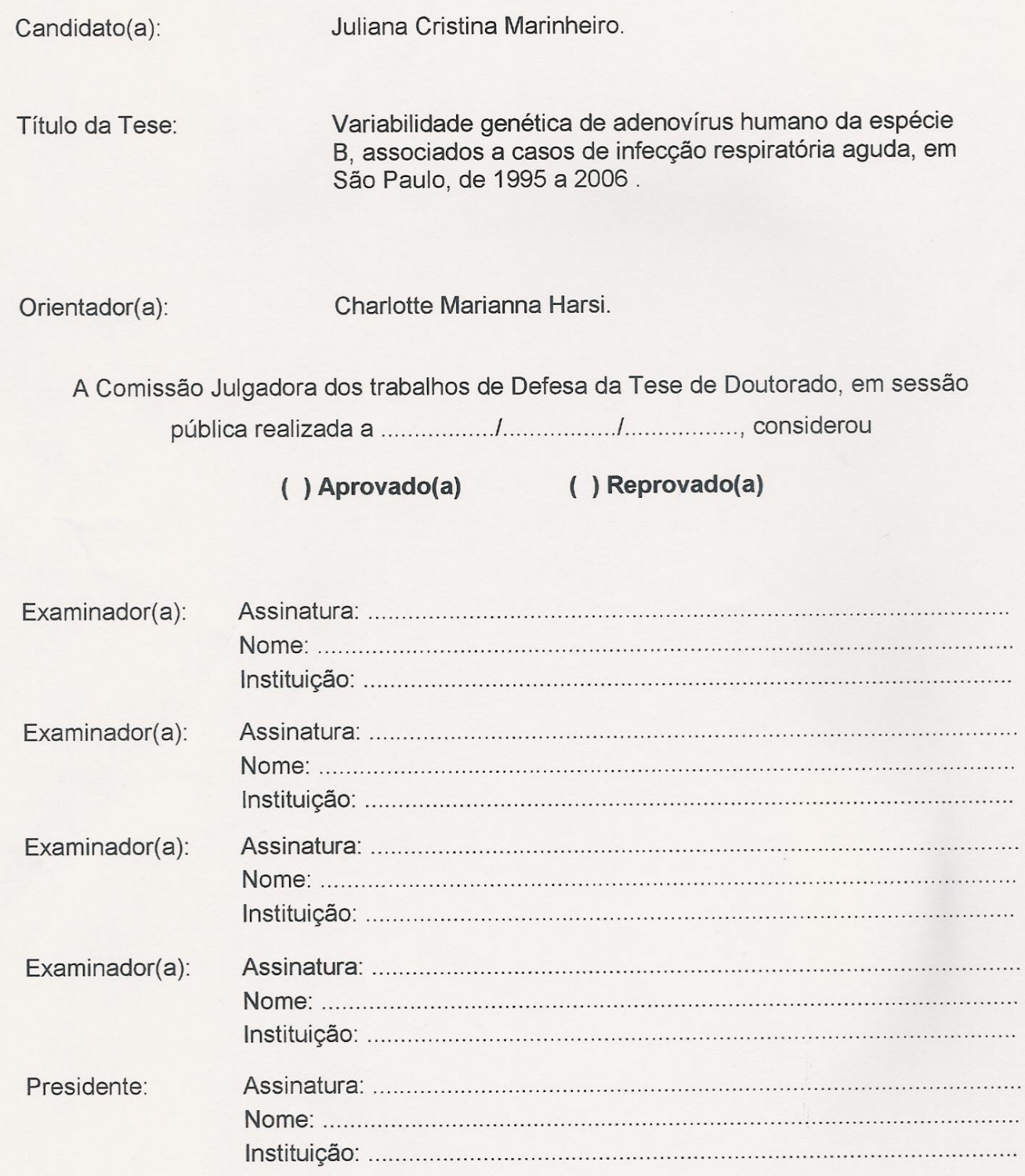


São Paulo, 11 de abril de 2007.

\section{PARECER 771/CEP}

Prezada Senhora,

Atendendo sua solicitação, a Comissão de Ética em Pesquisas com Seres Humanos do $I C B$, em sua $74^{a}$ reunião realizada em 10.04 .07 , analisou o projeto de sua responsabilidade intitulado: "Variabilidade Genética de Adenovirus Humanos das Espécies B E C, isolados de caso de Infecção Respiratória Aguda, em São Paulo, de 1995 A 2005".

Informo a V.Sa. que, após análise e discussão, o referido projeto foi aprovado por esta Comissão.

Lembramos que cabe ao pesquisador elaborar e apresentar a este Comitê, relatórios anuais (parciais ou final), de acordo com a resolução 196/06 do Conselho Nacional da Saúde, item IX.2 letra c.

O primeiro relatório deverá ser encaminhado à Secretaria deste CEP em 10 de abril de 2008.

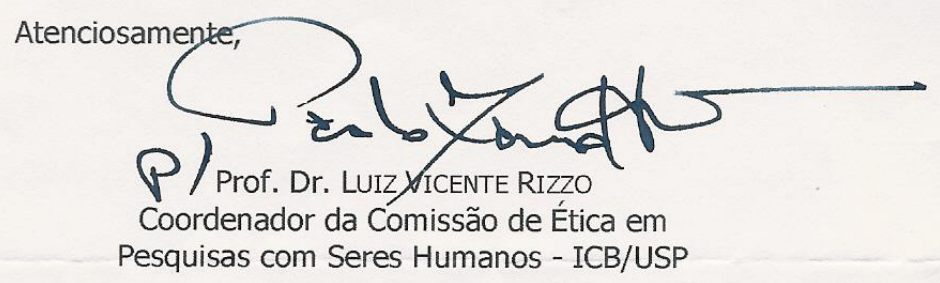

Ilma. Sra.

JULIANA CRISTINA MARINHEIRO

Departamento de Microbiologia

Instituto de Ciências Biomédicas -USP

Comissão de Ética em Pesquisa com Seres Humanos do Instituto de Ciências Biomédicas $/$ USP Aprovada pela Comissão Nacional de Ética em Pesquisa - CONEP, em 10 de fevereiro de 1998. 
Ao meu melhor amigo e companheiro de tantos anos, Maurinho Nê, Que é o meu maior incentivador e me faz muito feliz.

Aos meus queridos pais, Helena e Zezinho, Que têm me apoiado em todos os momentos da minha vida.

Ao теи irmão, Júnior, que sempre foi um grande amigo (volta logo, Ju).

Às minhas irmãs, Pudim, Six, Coca e Pri, Meninas, a gente não nasceu dos mesmos pais, mas não existe no mundo irmãs melhores que vocês. 


\section{AGRADECIMENTOS ESPECIAIS}

A Deus, que faz com que na vida, nada seja impossível.

À Professora Charlotte M Hársi,

Pela orientação na realização deste trabalho, pelos ensinamentos durante esses 11 anos (faz tempo hein, Cha?) e por todas as grandes oportunidades vivenciadas durante o doutorado.

Ao Dr. Dean Erdman, do Laboratório de Vírus Entéricos e Respiratórios do Centers for Disease Control and Prevention.

Pela grande oportunidade de realizar o estágio no CDC, onde pude aprender muito sobre os adenovírus pelos olhos de uns dos maiores especialistas do mundo.

\section{À Daniela Carvalho,}

Dani, nem sei o que dizer, obrigada por tudo, pela ajuda, pela amizade, pela viagem, por ser minha madrinha...

À Xiaoyan Lu, do Laboratório de Vírus Entéricos e Respiratórios do Centers for Disease Control and Prevention.

Por ter me ajudado muito no CDC.

Às minhas madrinhas e amigas, Pati Moura, Tati e Robs,

Por me ajudarem e me apoiarem tanto. Por serem minhas amigas para sempre. O laboratório não é o mesmo sem vocês.

Às queridas amigas, Jô, Pati Butantã e Veri,

Pelas conversas que ajudaram tanto durante este trabalho, pelas risadas, fofocas e, é claro, pela grande amizade.

Ao Carlos

Pelas palavras de incentivo, pelos maravilhosos cafés da manhã, e por ser um amigo tão leal.

À Fundação de Amparo à pesquisa do Estado de São Paulo (FAPESP),

Pela bolsa de doutorado concedida para a realização deste projeto. 


\section{AGRADECIMENTOS}

À Pri Ueno - que se tornou uma grande amiga, leal e verdadeira. Tô com saudade Pri!

À Dra. Teresa Peret, do Laboratório de Vírus Entéricos e Respiratórios do Centers for Disease Control and Preventio - pelas grandes conversas e por ter me ajudado tanto durante minha estadia no CDC.

Ao Dr. Mike McDonough e ao Dr. Steve Oberste, do Laboratório de Picornavírus, do Centers for Disease Control and Prevention - Por terem auxiliado durante minha estadia no CDC.

Ao pessoal do laboratório, de ontem e de hoje, Adri, Paty sem noção (que triou todas as amostras de 2006), Misa, Fê, Ariana - por terem ajudado tanto durante esta etapa.

Ao Prof. Dr. Edison Durigon, pela grande colaboração no desenvolvimento deste projeto.

Ao pessoal do laboratório da Profa. Dra. Dolores, Paty Garrafa (comigo desde a faculdade), Karina, Ariana, Telma, Fernanda - pela amizade e ajuda.

À Thais Rizzi - que me ajudou e escutou tanto no início do doutorado.

Ao pessoal do laboratório do Prof. Dr Edison Durigon (Clau, Dyana, Edu, Carolzinha, Dani, Teca, Lili, Angélica, Ju e Paty Bosso) - pela ajuda, pelos momentos de muita risada, de estress (né Clau?) e descontração no ICB.

Aos meninos do laboratório do Prof. Dr. Armando Ventura (Luís gatão, Cassiano, Tamura, Fernando) - pelas conversas no ICB, nos congressos e ajuda durante o doutorado.

Ao Prof. Dr. Carlos Frederico Menck - pelo uso dos equipamentos do seu laboratório.

Ao Prof. Dr. Armando Moraes Ventura - pelo uso dos equipamentos do seu laboratório.

Ao Prof. Dr Paolo Zanotto - que ajudou muito na elaboração deste projeto e, seus alunos Ju e Frank, que ajudaram com o sequenciamento.

À profa. Dra. Dolores Úrsula Menhert - Por ter me aceitado como estagiária e, pelo uso dos equipamentos do seu laboratório

Ao Prof. Dr Jorge Timenetsky - pelo uso do fotodocumentador.

Aos funcionários da secretária do Departamento de Microbiologia - pelas informações fornecidas durante esses 5 anos.

À Alice, secretária de pós-graduação da Microbiologia - por toda a paciência e pelas longas conversas. 
Aos funcionários do SAT (Seu José e Elaine) - sem o trabalho de vocês seria impossível desenvolver a pesquisa.

Aos funcionários da FAÍSCA - por manter o ICB sempre limpinho.

Aos funcionários da biblioteca (Maria José e Eva) - Por toda a paciência durante a elaboração da tese.

À equipe pedagógica do Colégio Barão de Mauá - Pela compreensão e apoio nesta etapa final da elaboração da tese.

Ao Nê - por ter me ajudado e me e apoiado durante todo o doutorado e por ter paciência nessa etapa estressante que é a entrega da tese.

À minha família, Pai, Mãe, Jú - Por sempre me apoiarem, me darem à mão quando eu caio e aplaudirem minhas conquistas.

À minha família, Vó, Tia Dê, Giovana e Ilda - Por estarem sempre próximas e ajudarem em tudo que precisamos.

Aos meus grandes amigos e padrinhos, Dilson, Marlene, Marilu - Por serem as pessoas maravilhosas que são e sempre torcerem por mim.

À minha sogra, Dna Inês, meus cunhados e sobrinhos - Pelos momentos de descontração.

À minha cahorrinha linda, Kaia - Por dar carinho e amor, em qualquer momento, sem pedir nada em troca. 
"O valor das coisas não esta no tempo que elas duram, mas na intensidade com que acontecem. Por isso existem momentos inesquecíveis, coisas inexplicáveis e pessoas incomparáveis”.

Fernando Sabino 


\section{RESUMO}

Marinheiro JC. Variabilidade genética de adenovírus humano da espécie B, associados a casos de infecção respiratória aguda, em São Paulo, de 1995 a 2006 [Tese de Doutorado]. São Paulo: Instituto de Ciências Biomédicas da Universidade de São Paulo; 2009.

Adenovírus humanos são responsáveis por infecção respiratória aguda (IRA) em crianças e adultos em todo o mundo. Crianças com infecção respiratória por adenovírus podem apresentar uma vasta variedade de sintomas, incluindo faringites, febre faringo-conjuntival, bronquites, bronquiolites e pneumonias. Adenovírus das espécies B (sorotipos 3 e 7) e C (sorotipos 1, 2, 5 e 6) são os mais frequentes no Brasil e, ocorrem durante todo o ano. Com o objetivo de estudar a variabilidade genética de adenovírus humanos, 3087 amostras de aspirado de nasofaringe foram colhidas de crianças internadas na enfermaria de pedriatria, do Hospital Universitário, USP, de 1995 à 2006. A PCR direcionada ao gene VA-RNA detectou dos adenovírus, sendo 677 adenovírus (22\%) detectados. Sequenciamento dos genes hexon, fibra e da região E3 foram utilizados para determinar o sorotipo e variabilidade genética dos adenovírus. As reações de sequenciamento, para cada gene, foram realizadas nas duas fitas do DNA usando o ABI Prism BigDye Terminator Cycle Ver 3.1. Sequências de nucleotídeos obtidas foram editadas e alinhadas. Dos 677 adenovírus detectados, 468 (69\%) foram classificados como espécie B (sorotipos 3, 7 e 21), 154 (23\%) como espécie C (sorotipos 1, 2, 5 e 6$)$ e $5(0,7 \%)$ como espécie E, sorotipo 4 . Infecções mistas por mais de um sorotipo foram observadas em 31 amostras (4,5\%). A maioria dos adenovírus sorotipo 7 detectados apresentou a proteína da fibra com maior similaridade à proteína dos adenovírus sorotipo 3 . Estes vírus são identificados como variante $7 \mathrm{~h}$. Análises filogenéticas do gene hexon mostraram a distribuição dos adenovírus em dois clusters principais, representando os sorotipos 3 e 7 e, cada um deles, subdividido em mais dois clusters representando as variantes $3 a, 3 p, 7 h$ e $7 p$, sendo esta reação eficiente para caracterização sorotípica. A mesma distribuição pôde ser observada com o sequenciamento da fibra, com excessão dos adenovírus $7 \mathrm{~h}$, que se agrupam no mesmo cluster do sorotipo 3. A proteína da região E3 que apresentou maior variabilidade foi a 7.7k, com tamanhos e aminoácidos bastante diversificados. É conhecido que genomas virais, incluindo dos adenovírus, podem se manter estáveis em condições diversas. Contuto, a existencia de variabilidade nos genomas pode sugerir que mecanismos evolutivos estão em operação. Os mecanismos evolutivos, já conhecidos para os adenovírus são observados como recombinações, captura gênica e duplicações. Mutações pontuais de um ou mais nucleotídeos podem ou não afetar a proteína sintetizada.

Palavras-Chave: Adenovírus humanos. Infecção Respiratória. Reação de Sequenciamento. Variabilidade Genética. Filogenia. 


\begin{abstract}
Marinheiro JC. Genetic variability of human adenoviruses species B associated to acute respiratory disease in children from São Paulo, Brazil, from 1995 to 2006 [PhD thesis]. São Paulo: Instituto de Ciências Biomedicas da Universidade de São Paulo; 2009.
\end{abstract}

Human adenoviruses cause acute respiratory disease (ARD) in children and adults around the world. Children with respiratory adenovirus may have a wide variety of symptoms including pharyngitis, tonsillitis, pharyngo-conjuntival fever, bronchitis, bronchiolitis and pneumonia. Adenoviruses of species B (serotypes 3 and 7) and C (serotypes 1, 2, 5 and 6) are the most frequently detected in Brazil associated to ARD and occurs during all the year. In order to study the genetic variability of human adenovirus, 3087 nasopharyngeal aspirate were collected from children attending at the Pediatric Ward of the University Hospital, USP, São Paulo (SP), from 1995 to 2006. PCR assay directed to adenovirus VA-RNA gene was used for the samples screening. 677 adenoviruses $(21,7 \%)$ were detected. The hexon, fiber and VARNA genes, as well, the E3 region of the adenovirus were sequenced to determinate the serotypes and study genetic variability. Sequencing reactions for each gene were performed in both strands of the DNA using the ABI Prism Bigdye Terminator Cycle Kit Ver. 3.1 on an ABI 3130 DNA Sequencer. Nucleotide sequences were assembled and edited with Sequencher software (GeneCode, USA) then aligned using ClustalW on the BioEdit software. Among the 677 adenovirus detected 468 (69 \%) were classified as HAdV-B (serotypes 3, 7 and 21$) ; 154(23 \%)$ as HAdV-C (serotypes 1, 2, 5 and 6) and $5(0,7 \%)$ as HAdV-E (serotype 4). Adenovirus HAdV-B, serotype 21 was detected only in two samples from 2006. Mixed infections with two different adenovirus species were observed in $31(4,5 \%)$ samples. The majority of the adenovirus serotype 7 presented the fiber gene similar to the serotype 3 . These viruses were characterized as genotype $7 \mathrm{~h}$. Phylogenetic analyses of the Species B adenoviruses hexon gene showed a distribution in two main clusters (serotypes 3 and 7) and beneath these groups in several clusters, with samples similar to prototype $3 p$ and $7 p$, others similar to variants ( $7 \mathrm{~h}$ and $3 \mathrm{a}$ ). The same distribution was observed after the analyses of the fiber gene sequences, except for $\mathrm{HAdV}-7 \mathrm{~h}$ samples which grouped again with the variant $3 \mathrm{a}$. The greatest variability was observed at the 7.7Orf of the E3 region. It is known that viral genomes, including adenovirus genome, remain genetically stable under a variety of conditions. However, the existence of multiple genome types could suggest that evolutionary mechanisms are operative. The mechanisms of adenovirus evolution and genomic diversity are specially observed in recombination, gene capture and gene duplication. Punctual mutations that change the nucleotide sequence could or not change the transcript protein.

Key words: Human adenovirus. Acute respiratory infection. Sequencing reaction. Genetic variability. Phylogeny. 


\section{LISTA DAS ILUSTRAÇÕES}

Figura 1: Distância filogenética entre os membros da família Adenoviridae. Cada gênero é representado por uma cor. Dentro dos gênero, os vírus que pertencem à mesma espécie são grupados por círculos ovais. As abreviações dos nomes dos vírus são indicadas ao final de cada ramificação, com o nome das espécies em itálico. A primeira letra indica o nome do animal do qual foi isolado o vírus: B (bovino); C (canino); D (pato); E (eqüino); F (galinha), Fr (sapo); H (humano); M (murino); O (ovino); P (suíno); Po (gambá); Sn (cobra); T (peru) e TS (primata primitivo). A distância filogenética foi calculada com base na sequiência nucleotídica do gene hexon, disponível no GenBank (Davison et al., 2003).....

Figura 2 - (A) Separação e identificação das proteínas do HAdV em SDS-PAGE; (B) - Representação esquemática da partícula do adenovírus e localização das suas proteínas. Fontes: Wadell et al., 1980; Russel, 2000 .

Figura 3 - Representação esquemática do genoma dos adenovírus, suas regiões de transcrição e genes. Modelo: Mastadenovirus SadV-25 (HAdV-E) (Davison et al, 2003).

Figura 4 - Transcrição do genoma dos adenovírus.As setas indicam a direção da transcrição (Russell, 2000).

Figura 5 - Organização gênica da região E3 dos adenovírus das espécies A-F (Burgert e Blusch, 2000)

Figura 6: Esquema da via de infecção do adenovírus. (1) Reconhecimento do CAR pela região globular da fibra; (2) Reconhecimento das integrinas pela penton-base; (3) Formação da fossa revestida por clatrina ; (4) Endocitose do adenovírus com formação da vesícula revestida por clatrina; (5) Liberação das fibras do adenovírus e acidificação do endossomo; (6) Lise do endossomo devido à interação da penton-base com a membrana; (7) Transporte do caspsídeo pela dineína migrando sobre o microtúbulo; (8) Interação do capsídeo com proteínas do poro nuclear; (9) Liberação do core no poro nuclear. Fonte: Modificado de Medina-Kauwe, 2003 por Siqueira-Silva, 2008.

Figura 7 - Localização dos primers elaborados para a amplificação da região E3 dos adenovírus espécie B

Figura 8 - Eletroforese em gel de agarose 1,0\% dos produtos da PCR, disrecionada ao gene VA-RNA. Mmarcador 1kb (BioLabs); C-: controle negativo da reação; Ad3: protótipo adenovírus sorotipo 3; Ad5: protótipo adenovírus sorotipo 5; cavidades 1,2, 4 e 6: adenovírus detectados de amostras coletadas entre 1995 e 2006 ; cavidades 3 e 5: amostras negativas.

Figura 9 - Eletroforese em gel de agarose 1,0\% dos produtos de Nested-PCR, direcionadas ao gene do hexon. M-marcador $100 \mathrm{pb}$ (BioLabs); Ad3: portótipo adenovírus sorotipo 3; cavidades 1 a 18: adenovírus detectados de amostras coletadas nos diferentes anos de estudo.

Figura 10- Frequência relativa de cada sorotipo de adenovírus detectado, por ano, 1995 a 2006. 59

Figura 11 - Distribuição mensal dos sorotipos e tipos genômicos de adenovírus detectados em amostras coletadas no ano de 1995. A: Distribuição em números absolutos de amostras coletadas e de adenovírus detectados; B: Frequência relativa dos adenovírus detectados nas amostras coletadas. Cada cor na figura representa um sorotipo/genotipo de adenovírus humanos.

Figura 12 - Distribuição mensal dos sorotipos e tipos genômicos de adenovírus detectados em amostras coletadas no ano de 1996. A: Distribuição em números absolutos de amostras coletadas e de adenovírus detectados; B: Frequência relativa dos adenovírus detectados nas amostras coletadas. Cada cor na figura representa um sorotipo/genotipo de adenovírus humanos. 
Figura 13 - Distribuição mensal dos sorotipos e tipos genômicos de adenovírus detectados em amostras coletadas no ano de 1997. A: Distribuição em números absolutos de amostras coletadas e de adenovírus detectados; B: Frequência relativa dos adenovírus detectados nas amostras coletadas. Cada cor na figura representa um sorotipo/genotipo de adenovírus humanos.

Figura 14- Distribuição mensal dos sorotipos e tipos genômicos de adenovírus detectados em amostras coletadas no ano de 1998. A: Distribuição em números absolutos de amostras coletadas e de adenovírus detectados; B: Frequência relativa dos adenovírus detectados nas amostras coletadas. Cada cor na figura representa um sorotipo/genotipo de adenovírus humanos.

Figura 15 - Distribuição mensal dos sorotipos e tipos genômicos de adenovírus detectados em amostras coletadas no ano de 1999. A: Distribuição em números absolutos de amostras coletadas e de adenovírus detectados; B: Frequência relativa dos adenovírus detectados nas amostras coletadas. Cada cor na figura representa um sorotipo/genotipo de adenovírus humanos.

Figura 16 - Distribuição mensal dos sorotipos e tipos genômicos de adenovírus detectados em amostras coletadas no ano de 2000. A: Distribuição em números absolutos de amostras coletadas e de adenovírus detectados; B: Frequência relativa dos adenovírus detectados nas amostras coletadas. Cada cor na figura representa um sorotipo/genotipo de adenovírus humanos.

Figura 17 - Distribuição mensal dos sorotipos e tipos genômicos de adenovírus detectados em amostras coletadas no ano de 2003. A: Distribuição em números absolutos de amostras coletadas e de adenovírus detectados; B: Frequência relativa dos adenovírus detectados nas amostras coletadas. Cada cor na figura representa um sorotipo/genotipo de adenovírus humanos.

Figura 18 - Distribuição mensal dos sorotipos e tipos genômicos de adenovírus detectados em amostras coletadas no ano de 2004. A: Distribuição em números absolutos de amostras coletadas e de adenovírus detectados; B: Frequência relativa dos adenovírus detectados nas amostras coletadas. Cada cor na figura representa um sorotipo/genotipo de adenovírus humanos

Figura 19- Distribuição mensal dos sorotipos e tipos genômicos de adenovírus detectados em amostras coletadas no ano de 2005. A: Distribuição em números absolutos de amostras coletadas e de adenovírus detectados; B: Frequência relativa dos adenovírus detectados nas amostras coletadas. Cada cor na figura representa um sorotipo/genotipo de adenovírus humanos.

Figura 20 - Distribuição mensal dos sorotipos e tipos genômicos de adenovírus detectados em amostras coletadas no ano de 2006. A: Distribuição em números absolutos de amostras coletadas e de adenovírus detectados; B: Frequência relativa dos adenovírus detectados nas amostras coletadas. Cada cor na figura representa um sorotipo/genotipo de adenovírus humanos.

Figura 21 - Comparação entre a quantidade de adenovírus detectados e o sexo da criança: Colunas em azul escuro e vermelho escuro representam o total de amostras de secração nasal coletadas em crianças de cada sexo; Colunas em azul claro e rosa representam os adenovírus detectados em amostras de coletadas de crianças de cada sexo.

Figura 22 - Quantidade de casos de infecção respiratória aguda causada por Adenovírus Humanos em diferentes faixas etárias. Cada cor, na figura, representa uma faixa etária.

Figura 23 - Frequência relativa de vírus respiratórios detectados em cada ano de coleta de amostras: HRSV: Vírus sincicial respiratório humano; Flu: Vírus da influenza; HMPV: Metapneumovírus humano; HAdV: Adenovírus humanos.

Figura 24 - Alinhamento das sequências de aminoácidos do gene do Hexon de alguns adenovírus detectados. Ad3a: Adenovírus sorotipo 3 variante 3a; Ad7h: Adenovírus sorotipo 7, variante 7h; HAdV.3p: protótipo adenovírus 3; HAdV7p: protótipo adenovírus 7. Em destaque, as 6 regiões hipervariáveis do hexon. 
Figura 25 - Árvore filogenética dos HadVs baseada no sequenciamento do gene do Hexon, regiões hipervariáveis 1-6. Dendograma construído a partir do método de análise evolutivo de Neighbor-joining. Comprimento do ramo indica a distância evolutiva entre as sequências.

Figura 26 - Eletroforese em gel de agarose 1,0\% dos produtos de Semi-Nested-PCR, direcionadas ao gene da fibra. M-marcador $100 \mathrm{pb}$ (BioLabs); Ad3: portótipo adenovírus sorotipo 3; cavidades 1 a 18: adenovírus detectados de amostras coletadas nos diferentes anos de estudo.

Figura 27 - Alinhamento das sequências de aminoácidos do gene de fibra de alguns adenovírus espécie B detectados: HAdV.7p: protótipo adenovírus sorotipo 7; HAdV-3p: protótipo adenovírus sorotipo 3; HAdV-7 vaccine: Adenovírus sorotipo 7 utilizado na fabricação de vacinas (sequência similar ao variante $7 \mathrm{~h}$ ). . .72

Figura 28 - Árvore filogenética, baseada no sequenciamento do gene da fibra, representando a relação de similaridade entre alguns adenovírus detectados. Dendograma construído a partir do método de análise evolutivo de Neighbor-joining. Comprimento do ramo indica a distância evolutiva entre as sequências

Figura 29 - Alinhamento da sequência de aminoácidos do gene VA-RNA de alguns adenovirus detectados. HAdV-3p: protótipo adenovirus sorotipo 3; HAdV-7p: protótipo adenovírus sorotipo 7; HAdV-7h: variante 7h; HAdV-2p: protótipo adenovírus sorotipo 2.

Figura 30 - Árvore filogenética baseada nas sequências de nucleotídeos do gene VA-RNA, demonstrando as relações de similaridades de alguns adenovírus detectados. Dendograma construído a partir do método de análise evolutivo de Neighbor-joining. Comprimento do ramo indica a distância evolutiva entre as sequências .76

Figura 31 - Eletroforese em gel de agarose 1,0\% dos produtos de Semi-Nested-PCR, direcionadas à região E3, ORFs 12.5K e 16K. M-marcador 100 pb (BioLabs); Ad3: portótipo adenovírus sorotipo 3; cavidades 1 a 18: adenovírus detectados de amostras coletadas nos diferentes anos de estudo.

Figura 32 - Alinhamento da sequência de aminoácidos doas proteínas $12.5 \mathrm{~K}$ e $16.1 \mathrm{~K}$ da região E3 do genoma dos adenovírus humanos : HAdV.3p: protótipo sorotipo 3; HAdV.7p: protótipo sorotipo 7.

Figura 33- Árvore filogenética de alguns adenovírus detectados durante esse estudo com relação as proteinas $12.5 \mathrm{~K}$ e $16.1 \mathrm{~K}$ da região E3 do genoma dos adenovírus humanos. Dendograma construído a partir do método de análise evolutivo de Neighbor-joining. Comprimento do ramo indica a distância evolutiva entre as sequências.

Figura 34 - Eletroforese em gel de agarose 1,0\% dos produtos de Nested-PCR, direcionadas à região E3, ORF 19K. M-marcador $100 \mathrm{pb}$ (BioLabs); Ad3: portótipo adenovírus sorotipo 3; cavidades 1 a 18: adenovírus detectados de amostras coletadas nos diferentes anos de estudo.

Figura 35 - Alinhamento das sequências de aminoácidos da proteína $19.5 \mathrm{~K}$ da região E3 d genoma dos adenovírus humanos: HadV-3p: protótipo adenovírus sorotipo 3; HAdV-7: protótipo adenovírus sorotipo 7 ......82

Figura 36 - Árvore filogenética referente às sequências de aminoácidos da proteína 19.5k, da região E3 do genoma dos adenovírus humanos. Dendograma construído a partir do método de análise evolutivo de Neighborjoining. Comprimento do ramo indica a distância evolutiva entre as sequências.

Figura 37 - Eletroforese em gel de agarose 1,0\% dos produtos de Nested-PCR, direcionadas à região E3, ORF 7.7. M-marcador $100 \mathrm{pb}$ (BioLabs); Ad3: portótipo adenovírus sorotipo 3; cavidades 1 a 18: adenovírus detectados de amostras coletadas nos diferentes anos de estudo.

Figura 38 - Alinhamento dos aminoácidos da proteína 7.7K dos adenovírus humanos da espécie B detectados na amostragem estudada. HAdV-3p: protótipo sorotipo 3; HAdV-3a:variante sorotipo 3; HAdV-7h: variante 7h; HAdV-7p: protótipo sorotipo 7.

Figura 39 - Árvore filogenética baseada no sequenciamento da proteína 7.7 da região E3 do genoma dos adenovírus humanos espécie B. Dendograma construído a partir do método de análise evolutivo de Neighborjoining. Comprimento do ramo indica a distância evolutiva entre as sequências. 


\section{LISTA DE TABELAS}

Tabela 1: Classificação dos sorotipos de HAdVs dentro das espécies e suas principais características...............22

Tabela 2: Localização e função das proteínas presentes nos adenovírus (Siqueira-Silva, 2008) .25

Tabela 3 - Sequência de nucleotídeos dos primers direcionados ao gene VA-RNA para detecção dos adenovírus humanos nas amostras.

Tabela 4 - Sequência de nucleotídeos dos primers direcionados à região do Hexon do genoma adenoviral, utilizados para identificação das epécies e sorotipos dos adenovírus detectados.

Tabela 5: Distribuição dos adenovírus detectados por PCR de amostras de secreção de nasofaringe, nos diferentes anos de estudo e, suas respectivas espécies determinadas por sequenciamento do gene hexon 59

Tabela 6 - Relação dos oligonucleotídeos elaborados para amplificação do gene da fibra e região E3. 67 


\section{LISTA DE ABREVIATURAS}

$\%:$ Porcentagem

${ }^{\circ} \mathrm{C}$ : Graus centígrados

$\mu \mathrm{L}$ Microlitro

$\mu \mathrm{M}$ : Micromolar

A: Adenina

aa: Aminoácidos

AIDS: Síndrome da Imunodeficiência Adquirida

ddNTP: 2', 3'didesoxirribonucleotídeo trifosfato

DNA: Ácido desoxirribonucleico

dNTPs: Desoxirribonucleotídeos Fosfatados (N: A, C, G ou T)

EDTA: ácido etilenodiaminotetracético

HAdV: Adenovírus Humano

HVR: Região Hipervariável

IRA: Infecção Respiratória Aguda

$\mathrm{Kb}$ : Kilo-base

$\mathrm{KCl}$ : Cloreto de potássio

$\mathrm{MgCl}_{2}$ : Cloreto de Magnésio

mL: Mililitros

mM: Milimolar

$\mathrm{NaCl}$ : Cloreto de sódio

$\mathrm{NaOH}$ : Hidróxido de sódio

nm: Nanômetro

ORF: Região Aberta de Leitura

pb: pares de bases

PBS: Solução Salina Fosfatada

PCR : Reação em cadeia da polimerase

pH: Potencial hidrogeniônico

pmoles: Picomoles

RFLP: Restriction Fragment Length Polymorphisms

RNA: Ácido ribonucleico

RPM: Rotações por minuto 
Pro: Prolina

RPM: Rotações por minuto

Ser: Serina

SDS: dodecil sulfato de sódio

TAE: Tampão contendo Tris, Ácido Acético e EDTA

TBE: Tampão Tris-Borato

TE: Tampão Tris EDTA

TP: Proteína Terminal

U: Unidade

UV: Ultravioleta

VER: Versão 


\section{SUMÁRIO}

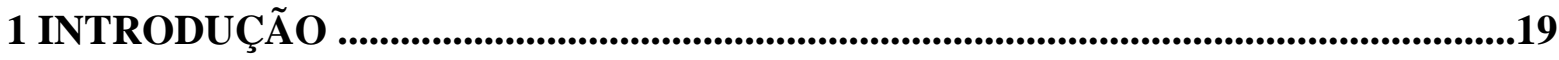

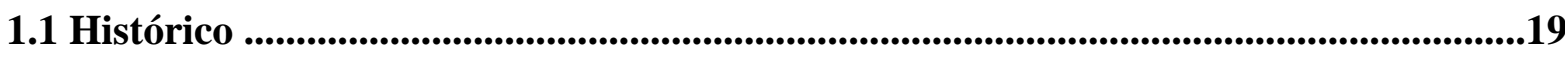

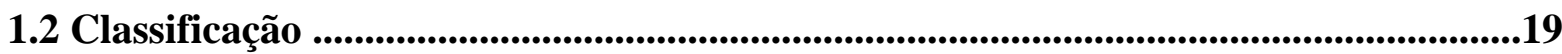

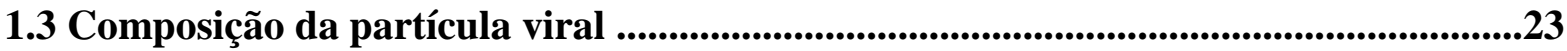

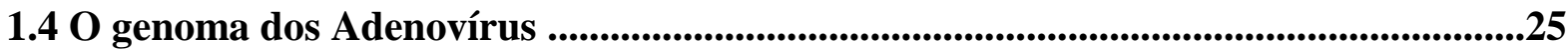

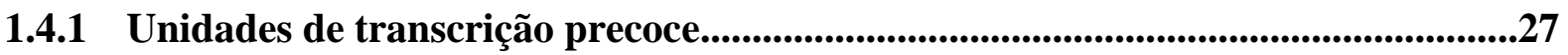

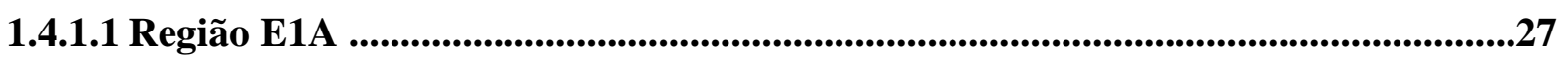

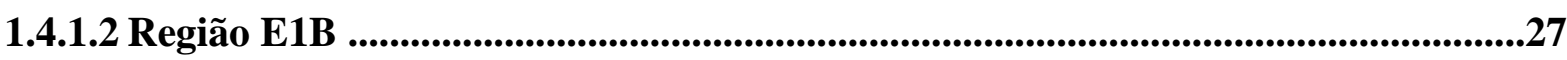

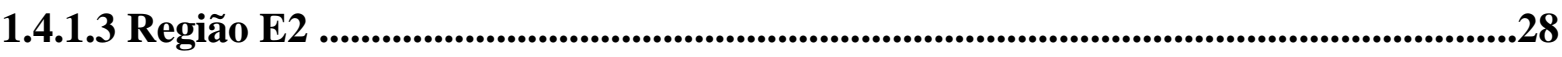

1.4.1.4 Região E3 .................................................................................................................................28

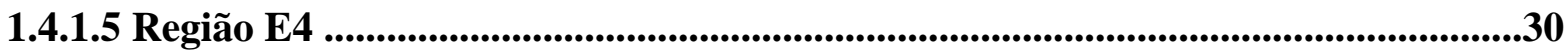

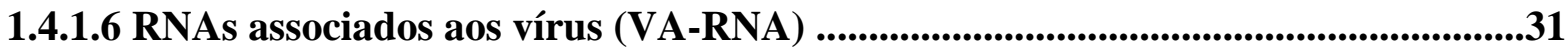

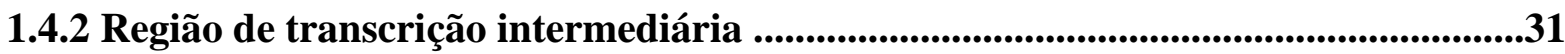

1.4.3 Unidade de transcrição tardia .......................................................................................32

1.5 Entrada do vírus na célula e replicação viral ......................................................32

1.6 Resposta do hospedeiro à infecção por adenovírus .................................................35

1.7 Epidemiologia dos adenovírus humanos ...............................................................36

1.7.1 Adenovírus humanos em infecções respiratórias ...................................................38

1.8 Métodos de detecção e caracterização dos adenovírus........................................................39

1.9 Evolução viral ............................................................................................................................................41

2 OBJETIVOS ..................................................................................................................44

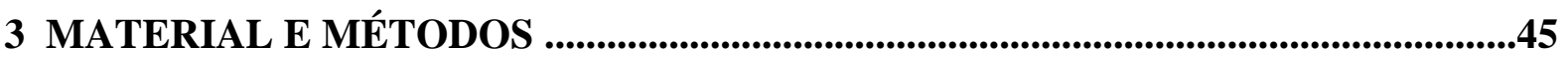

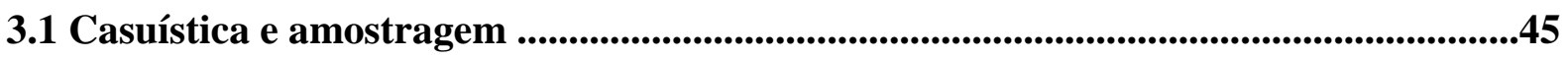

3.2 Vírus Padrão ...........................................................................................................................................45

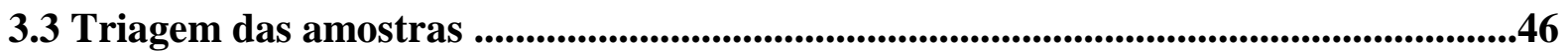

3.3.1 Extração do DNA viral ....................................................................................................46

3.3.2 Detecção e Caracterização dos Adenovírus Humanos ..............................................47

3.3.2.1 Reação de PCR para amplificação do gene VA-RNA .............................................47

3.3.2.2 PCR e Nested-PCR para amplificação da região do Hexon .......................................48

3.3.2.3 Sequenciamento do produto da região do Hexon..................................................49

3.3.2.4 Edição e análise das sequências ........................................................................................50 
3.4 Estudo da Variabilidade Genética dos adenovírus espécie B .50

3.4.1 Escolha das regiões estudadas ........................................................................................50

3.4.2 Desenho de oligonucleotideos ...........................................................................50

3.4.3 Padronização das reações de amplificação do DNA. ....................................................52

3.4.4 PCR e Semi-Nested-PCR direcionado à fibra ..............................................................52

3.4.5 PCR e Nested-PCR direcionados à região E3 ...........................................................53

3.4.6 Purificação dos produtos de PCR .......................................................................54

3.4.7 Reações de sequenciamento ................................................................................54

3.4.8 Edição e Análise das reações de sequenciamento .............................................................55

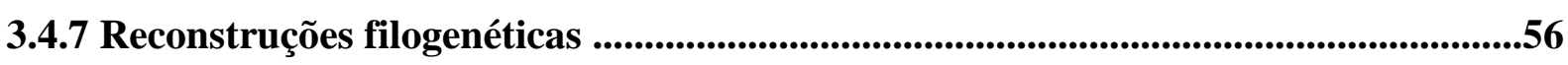

3.5 Análises Epidemiológicas ...........................................................................................56

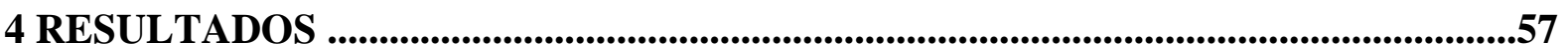

4.1 Detecção e caracterização dos Adenovírus Humanos ................................................57

4.1.1 PCR para amplificação do gene VA-RNA ..........................................................57

4.1.2 PCR e Nested- PCR direcionados à região do Hexon ..............................................57

4.1.3 Sequenciamento do produto de PCR da região do Hexon. ........................................58

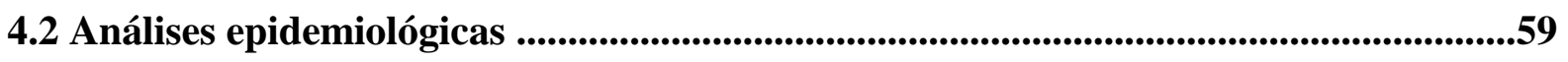

4.3 Estudo da Variabilidade genética dos adenovírus humanos espécie B ......................66

4.3.1 Desenho dos oligonucleotídeos para amplificação e sequenciamento .......................66

4.3.2 Variabilidade genética do Hexon ...........................................................................67

4.3.3 Variabilidade genética da Fibra ............................................................................11

4.3.4 Variabilidade genética do gene VA-RNA ..........................................................74

4.3.5 Variabilidade genética da região E3 ..................................................................77

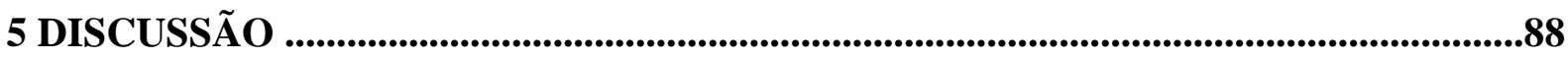

5.1 Caracterização dos adenovírus humanos associados à infecção respiratória aguda88

5.2 Estudo da variabilidade genética dos adenovírus humanos ..............................................94

6 CONCLUSÃ O.............................................................................................................99

REFERÊNCIAS BIBLIOGRÁFICAS.................................................................................101

Anexo 1: Lista de Aminoácidos e Suas Abreviações ....................................................121 


\section{INTRODUÇÃO}

Os adenovírus humanos (HAdVs) compreendem um importante grupo de agentes etiológicos, responsáveis por diversas patologias, em adultos e crianças, como: infecções respiratórias, oculares, gastrentéricas e urinárias. Estes vírus podem, também, ser isolados das fezes de pacientes assintomáticos por meses após a infecção. Em indivíduos imunocomprometídos, como pacientes com Síndrome da Imunodeficiência Adquirida (AIDS) e transplantados, podem causar infecções generalizadas.

\subsection{Histórico}

Os adenovírus humanos foram primeiramente isolados em 1953 por Rowe et al. quando tentavam estabelecer uma linhagem celular de tecido adenoide removido cirurgicamente de crianças e de recrutas militares com doenças febris. Os autores descreveram que encontraram um agente que causava degeneração espontânea nestas células epiteliais.

Em 1954, Hillerman e Werner, estudando uma epidemia de doença respiratória em recrutas, descreveram um agente similar, que induzia efeito citopático (ECP) em culturas de células humanas. Esses vírus foram primeiramente denominados "adenoid degeneration" (AD), "adenoid-pharyngealconjuntuval" (APC) e "acute respiratory disease agents"(ARD). A nome adenovírus, nomenclatura atual, foi criado por Enders e colaboradores, em 1956.

Em 1962, Trentin et al. descreveram pela primeira vez que um vírus humano poderia induzir o desenvolvimento de tumores malignos em animais. Eles observaram que um sorotipo de adenovírus humano (sorotipo 12) era capaz de induzir o desenvolvimento de tumores em roedores e que as células transformadas seriam capazes de produzir novos tumores, quando inoculadas em animais imunologicamente compatíveis.

\subsection{Classificação}

De acordo com o Comitê Internacional de Taxonomia Viral (ICTV-International Committee on Taxonomy of Viruses), os adenovírus pertencem à família Adenoviridae, que é dividida em 4 gêneros filogenicamente distintos: Mastadenovirus (vírus que infectam mamíferos), Aviadenovirus (vírus que infectam aves), Atadenovirus (vírus que infectam ruminantes, répteis e marsupiais) e Siadenovirus (vírus que infectam aves, anfíbios e peixes). (Davison et al., 2003) 
Os adenovírus de cada um desses gêneros diferem entre si por várias características morfológicas e genéticas. Os Aviadenovirus, por exemplo, apresentam uma partícula viral com DNA de peso molecular variando entre 28 e $30 \mathrm{Md}$, percentual em bases guanina e citosina $(\mathrm{G}+\mathrm{C})$ variando entre 51 e $57 \%$ e duas fibras por vértice, o que confere a esse vírus a capacidade de reconhecer dois receptores distintos nas células do hospedeiro. Os adenovírus do gênero Mastadenovirus possuem somente uma fibra por vértice, cujo comprimento varia entre 10 e $30 \mathrm{~nm}$. O DNA possui peso molecular de 20 a $25 \mathrm{Md}$, com percentual de $\mathrm{G}+\mathrm{C}$ entre 44 e $61 \%$. Os adenovírus humanos sorotipos 40 e 41, diferentemente aos demais Mastadenovirus, possuem a presença de duas fibras de comprimentos diferentes, codificadas por dois genes distintos, porém distribuídas uma por vértice. (Kidd et al., 1990; Pieniazek et al., 1990). Uma das duas fibras, chamada fibra longa, foi provavelmente adquirida por recombinação com DNA de adenovírus que infecta macacos (Kidd et al., 1990).

A figura 1 apresenta a árvore de distância filogenética dos membros da família Adenoviridae (Davison et al., 2003).

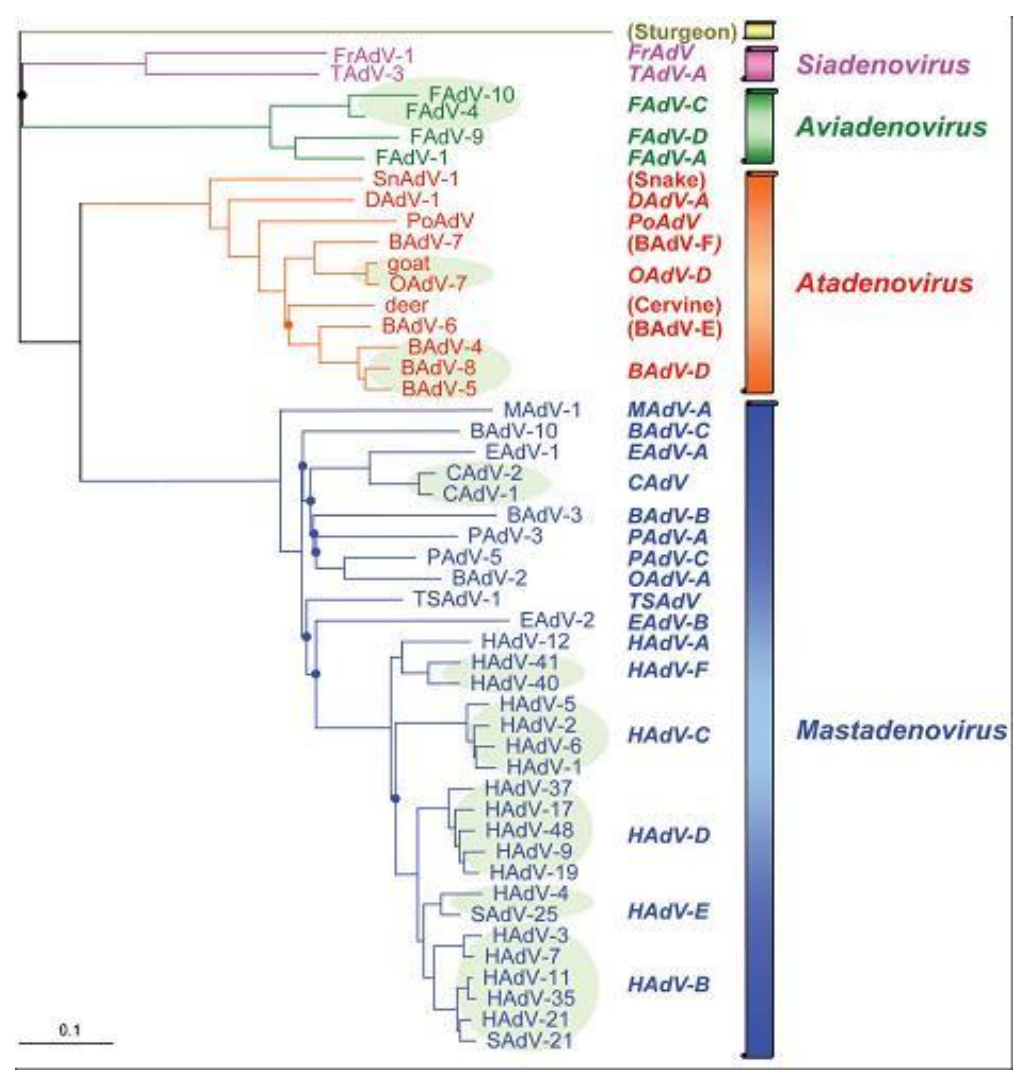

Figura 1: Distância filogenética entre os membros da família Adenoviridae. Cada gênero é representado por uma cor. Dentro dos gênero, os vírus que pertencem à mesma espécie são agrupados por círculos ovais. As abreviações dos nomes dos vírus são indicadas ao final de cada ramificação, com o nome das espécies em itálico. A primeira letra indica o nome do animal do qual foi isolado o vírus: B (bovino); C (canino); D (pato); E (eqüino); F (galinha), Fr (sapo); H (humano); M (murino); O (ovino); P (suíno); Po (gambá); Sn (cobra); T (peru) e TS (primata primitivo). A distância filogenética foi calculada com base na seqüência nucleotídica do gene hexon, disponível no GenBank (Davison et al., 2003). 
Atualmente há uma discussão científica sobre a criação de um quinto gênero, Fishadenovirus, devido à identificação de um adenovírus isolado em esturjão, cujas características não se enquadram em nenhum dos gêneros existentes (Davison et al., 2003).

Os adenovírus humanos pertencem ao gênero Mastadenovirus. Estes vírus têm a habilidade de infectar uma vasta gama de tecidos, sendo identificados como agentes etiológicos de diversas patologias, como por exemplo: síndromes respiratórias, ceratoconjuntivites, infecções entéricas e renais. A classificação atual reconhece 51 sorotipos humanos divididos em seis espécies (de A à F). Esta divisão se dá de acordo com características antigênicas, morfológicas e moleculares (Tiemessen e Kidd, 1995; Wadell, 1984).

Um novo sorotipo, HAdV-52, foi descrito recentemente de casos de gastrenterites e, devido suas características distintas, é sugerida sua classificação em uma nova espécie, G (Jones II et al., 2007). Este novo sorotipo, até o momento, não aparece na página de classificação dos adenovirus no ICTV.

A primeira classificação, proposta por Rosen et al. (1960), foi baseada na aglutinação de hemáceas de ratos e de macaco "rhesus". Reações cruzadas na inibição de hemaglutinação foram verificadas em alguns sorotipos e linhagens intermediárias (Wigand et al., 1985, 1987).

Huebner et al. (1965) sugeriram a distribuição dos adenovírus em grupos, baseada na patogenicidade e oncogenicidade em hamsters recém-nascidos. A atual espécie A compreende os sorotipos que apresentam alta capacidade transformante; a espécie B compreende os sorotipos com oncogenicidade moderada; as demais espécies agrupam os adenovírus considerados não oncogênicos.

Em 1979, Wadell propôs a classificação dos adenovírus com base no peso molecular dos polipeptídeos estruturais. Uma variação no peso molecular das proteínas II, III e IV foi observada entre cada sorotipo.

Levando em consideração a diferença na sequência de nucleotídeos do genoma viral e sabendo que as concentrações de $\mathrm{G}+\mathrm{C}$ no DNA dos adenovírus das diferentes espécies é variável, Wadell e colaboradores (1980) analisaram os padrões de restrição do genoma de vários sorotipos de adenovírus, após digestão com a enzima Sma I. Essa enzima tem como sítio de restrição a sequência 5'CCC GGG. Neste estudo, os autores observaram que o número de fragmentos obtidos era característico para cada espécie e que os membros de uma mesma espécie apresentavam vários fragmentos co-migrantes. 
A definição dos sorotipos é feita após realização de ensaios de neutralização da infecção viral em cultura de células permissivas. São considerados como sendo sorotipos distintos os vírus que não apresentarem reações cruzadas com outros sorotipos ou que apresentarem títulos neutralizantes maiores que 16. Em casos em que ocorre reação cruzada, são realizados os testes de hemaglutinação e restrição do DNA com endonucleases de restrição (Wigand e Adrian, 1986).

A tabela 1 apresenta a classificação sumarizada dos adenovírus humanos e suas propriedades.

Tabela 1: Classificação dos sorotipos de HAdVs dentro das espécies e suas principais características.

\begin{tabular}{|c|c|c|c|c|c|c|}
\hline & Espécie A & Espécie B & Espécie C & Espécie D & Espécie E & Espécie F \\
\hline Sorotipos & $12,18,31$ & $\begin{array}{c}3,7,11,14,16,21,3 \\
4,35,50\end{array}$ & $1,2,5,6$ & $\begin{array}{c}8,10,13,15,17,19, \\
20,22- \\
30,32,33,36- \\
39,42-47,51\end{array}$ & 4 & $40-41$ \\
\hline Similaridade $(\%)^{\mathrm{a}}$ & $48-69$ & $89-94$ & $99-100$ & $94-99$ & $4-23$ & 62 \\
\hline Percentual G+C & 48 & 51 & 58 & 58 & 58 & - \\
\hline $\begin{array}{l}\text { Perfil de restrição } \\
\text { com a SmaI }\end{array}$ & $4-5$ & $8-10$ & $10-12$ & $14-18$ & $16-19$ & $9-12$ \\
\hline $\begin{array}{c}\text { Padrão } \\
\text { hemaglutinante }^{b}\end{array}$ & IV & I & III & II & III & IV \\
\hline Oncogenecidade & Alta & Fraca & Negativa & Negativa & Negativa & Negativa \\
\hline Receptor da fibra $^{c}$ & CAR & $\begin{array}{c}\text { CD46, CD80 e } \\
\text { CD86 }\end{array}$ & $\begin{array}{c}\text { CAR } \\
\text { VCAM } 1 \\
\text { Sulfato de } \\
\text { Heparana }\end{array}$ & CAR, ácido siálico & CAR & $\begin{array}{c}\text { CAR }^{\mathrm{C}} \\
\mathrm{e} \\
\text { desconhecido }^{-}\end{array}$ \\
\hline $\begin{array}{l}N^{0} \text { de genes VA- } \\
\text { RNA }\end{array}$ & 1 & $\begin{array}{l}2(\mathrm{~B} 1) \\
1(\mathrm{~B} 2)\end{array}$ & 2 & 2 & 2 & 1 \\
\hline$N^{\circ}$ de ORF em E3 & 6 & $\begin{array}{l}9 \text { (B1) } \\
8 \text { (B2) }\end{array}$ & 7 & 8 & 9 & 5 \\
\hline $\begin{array}{c}\text { Motivos da } \\
\text { penton-base }^{\mathrm{d}}\end{array}$ & RGD e LDV & RGD e LDV & RGD e LVD & RGD e LDV & RGD e LDV & $\begin{array}{c}\text { LDV } \\
\text { RGDA(40) } \\
\text { IGDD (41) }\end{array}$ \\
\hline $\begin{array}{l}\text { Comprimento da } \\
\text { fibra (repetição dos } \\
\text { motivos) }\end{array}$ & 22 & $\begin{array}{l}6(\mathrm{~B} 1) \\
6(\mathrm{~B} 2)\end{array}$ & 22 & 8 & 12 & $\begin{array}{l}\text { Longa:21-22 } \\
\text { Curta: } 12\end{array}$ \\
\hline Tropismo & Entérico & $\begin{array}{l}\text { Respiratório (B1) } \\
\text { Renal (B2) }\end{array}$ & Respiratório & Ocular & $\begin{array}{c}\text { Ocular } \\
\text { respiratório }\end{array}$ & Entérico \\
\hline Síndromes & Gastrenterites & $\begin{array}{c}\text { Respiratória } \\
\text { aguda } \\
\text { Infecções Renais } \\
\text { persistentes }\end{array}$ & $\begin{array}{c}\text { Respiratória } \\
\text { Aguda }\end{array}$ & $\begin{array}{l}\text { Ceratoconjuntivite } \\
\text { Inaparente }\end{array}$ & $\begin{array}{l}\text { Conjuntivite } \\
\text { Respiratória } \\
\text { aguda }\end{array}$ & $\begin{array}{l}\text { Gastrenterite } \\
\text { infantil }\end{array}$ \\
\hline
\end{tabular}

a: Porcentagem de homologia entre as espécies

b: Padrão de hemaglutinação: I- aglutinação completa de eritrócitos de macaco; II- aglutinação completa de eritrócitos de rato; III- aglutinação parcial de eritrócitos de rato, IV- aglutinação de eritrócitos de ratos após a adição de anti-soro heterotípico.

c: fibra longa da espécie F se liga ao CAR, mas a fibra curta não tem receptor conhecido.

d: motivos expostos na penton-base através dos quais ocorre o reconhecimento dos receptores secundários, integrinas (Modificado de Segerman, 2004). 


\subsection{Composição da partícula viral}

Os adenovírus são vírus não envelopados, de simetria icosaédrica regular (vinte faces triangulares e doze vértices), com 70 a 100 nm de diâmetro (Benko e Harrach, 2003; Russel, 2000). Sua densidade, quando medida em gradiente de cloreto de césio, é de 1,33 à $1,34 \mathrm{~g} / \mathrm{cm}^{3}$. São estáveis em pH entre 6,0 e 9,0 e não possuem envelope lipoproteico, por isso, podem ser estocados por períodos prolongados em diferentes temperaturas. Estes vírus não são sensíveis ao tratamento com solventes orgânicos como éter e etanol e podem ser liofilizados, sem alteração de sua infectividade, quando estocados à $4{ }^{\circ} \mathrm{C}$ (Horwitz, 1996; Wassemann, 1962).

A partícula viral é constituída por 11 proteínas, denominadas polipeptídeos (II, III, IIIa, IV, V, VI, VII, VIII, IX, X e TP). Estas proteínas são numeradas com relação a sua migração em gel de poliacrilamida SDS (SDS-page), conforme ilustrado na figura 2A. Das 11 proteínas, 7 compõem o capsídeo viral (II, III, IV, IIIa, VI, VIII e IX). O capsídeo contém 252 subunidades chamadas capsômeros, das quais 240 são constituídas pela proteína hexon (pII), compondo as faces do icosaedro. Os 12 capsômeros restantes são compostos pelas proteínas penton-base (pIII) e fibra (pIV), que formam os vértices (Figura 2B).
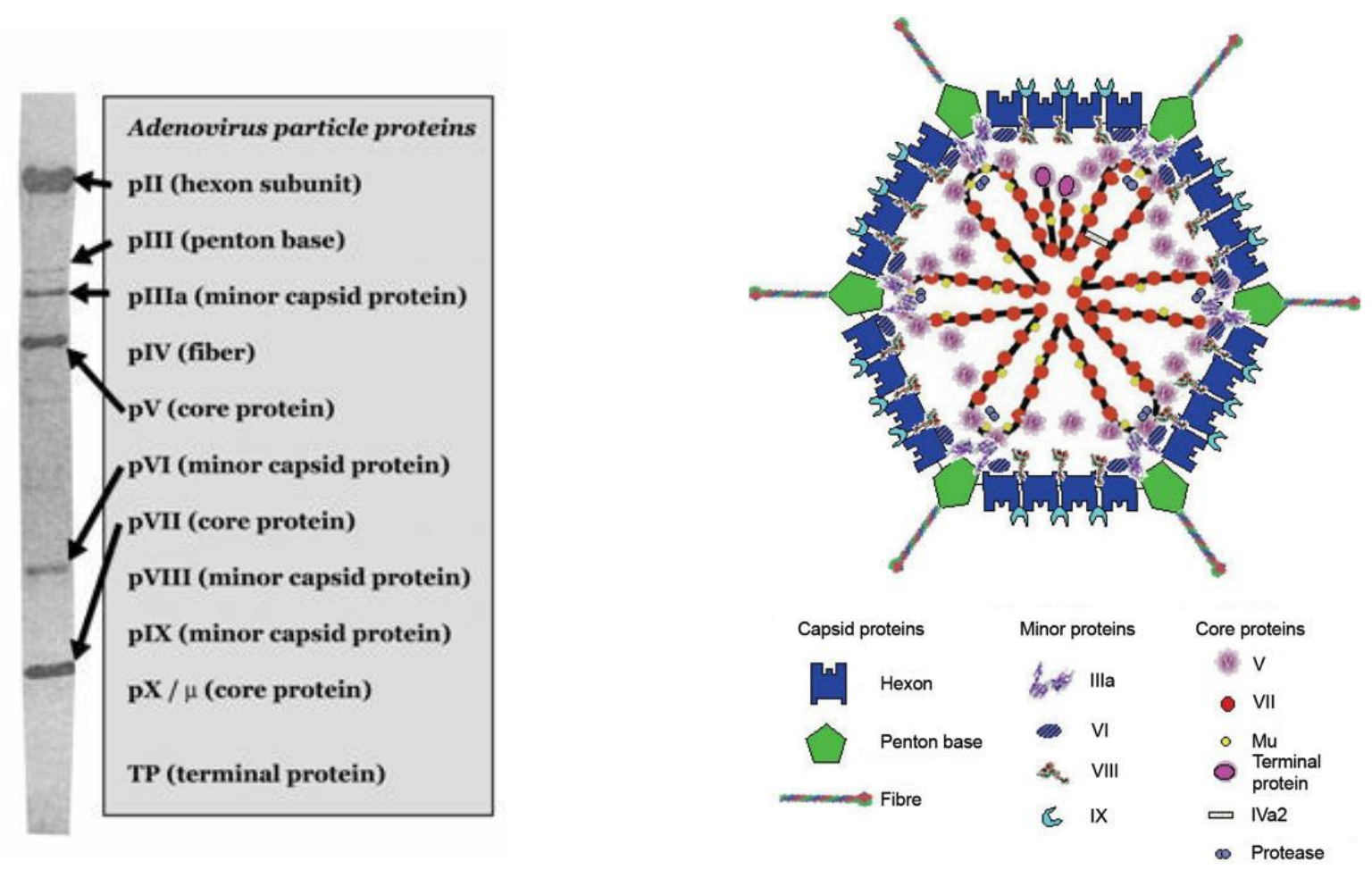

Figura 2 - (A) Separação e identificação das proteínas do HAdV em SDS-PAGE; (B) - Representação esquemática da partícula do adenovírus e localização das suas proteínas (Russel, 2000; Wadell et al., 1980). 
O tamanho da molécula do hexon pode variar entre os sorotipos de adenovírus, sendo, por exemplo, de 967aa para adenovírus sorotipo 2. Existem 7 regiões hipervariáveis na proteína hexon, relacionadas aos epítopos determinantes de sorotipo e atividade reconhecida pelos anticorpos neutralizantes (Roberts et al., 2006; Russel, 2009).

Os polipeptídios pVI, pVIII e pIX encontram-se associadaos à proteína hexon, sendo responsáveis pela estabilidade e flexibilidade da partícula viral (Greber et al., 1998; Vellinga et al., 2005). A proteína pIIIa está situada no vértice do icosaédro, e junto com o hexon formam faces triangulares, determinando o formato do virion, sendo necessário para que ocorra a formação correta da partícula viral. Vírus com mutações que afetam a pIIIa, são defectivos e formam partículas virais deficientes (Vellinga et al., 2005).

As proteínas pVI e pVIII estão associadas à superfície interna do capsídeo viral. Estudos sugerem que a pVI pode interagir diretamente com o DNA viral, sendo ela a proteína responsável por manter o contato do hexon com o core (San Martin e Burnett, 2003; Stewart et al., 1993). Durante a infecção, a proteína VI pode ajudar a partícula viral a escapar do endossomo celular, pois ela induz a ruptura da membrana endocítica (Wiethoff et al., 2005). Outra função importante da pVI é facilitar a importação da proteína hexon para o núcleo celular, onde é montada a partícula viral (Matthews e Russel, 1995).

Até o momento, a proteína VIII é a menos conhecida. Estudos utilizando mutantes defectivos nesta proteína sugerem que ela pode estar relacionada com a estabilidade da estrutura do virion (Liu et al., 1985).

A proteína penton-base dos adenovírus sorotipo 2 contém 471 aminoácidos e encontra-se complexada à fibra (582 aminoácidos). A fibra dos adenovírus 2 contém 582 aa e é dividida em três domínios: a cauda (porção N-terminal) encontra-se ligada a base do pentons; a haste, ou parte central, encontra-se ligada à região globular (porção C-terminal). Grande parte da sequência de aminoácidos da fibra não é conservada, isso faz com que ocorram variações antigênicas entre os diferentes sorotipos de adenovírus, porém, a região próxima à $\mathrm{N}$ terminal é descrita como altamente conservada entre os sorotipos (Russel, 2009; Shenk, 2001; Tarassishin et al., 2000).

O core viral é composto pela molécula de DNA dupla fita, com $36 \mathrm{~Kb}$. Associadas ao DNA viral encontram-se quatro proteínas. A TP (terminal protein), ligada covalentemente à extremidade 5' de cada fita de DNA, que tem como função iniciar a replicação do DNA (Shenk, 1996). A proteína pVII, majoritária no cerne viral, desempenha a função de histona, sendo responsável pela compactação e organização do material genético no interior do 
capsídeo viral (Chatterjee et al., 1986). A proteína $\mathrm{pV}$ ancora o DNA viral ao vértice do capsídeo, por meio da interação com a proteína penton-base (San Martin e Burnett, 2003). A proteína pX é clivada na proteína $m u$, a qual está presente em partículas virais maduras, no entanto, sua função permanece desconhecida (Shenk et al., 1996).

A tabela 2 apresenta as proteínas presentes na partícula viral, bem como suas localizações e funções.

Tabela 2: Localização e função das proteínas presentes nos adenovírus (Siqueira-Silva, 2008).

\begin{tabular}{|c|c|c|}
\hline Proteína (polipeptídeo) & Localização no virion & Funções \\
\hline II & Monômero do hexon & $\begin{array}{l}\text { Majoritaria no capsídeo } \\
\text { (estrutural) }\end{array}$ \\
\hline III & Base do penton & Penetração na célula \\
\hline IIIa & Associada à base do penton & $\begin{array}{l}\text { Formação da partícula viral; } \\
\text { Estabilização }\end{array}$ \\
\hline IV & Fibra & $\begin{array}{l}\text { Reconhecimento do receptor } \\
\text { primário }\end{array}$ \\
\hline $\mathrm{V}$ & $\begin{array}{l}\text { Core: associado ao DNA e à base } \\
\text { do penton; peptídeo associado ao } \\
\text { penton }\end{array}$ & Empacotamento \\
\hline VI & Peptídeo associado ao hexon & $\begin{array}{l}\text { Contato do hexon com o core } \\
\text { estabilização. }\end{array}$ \\
\hline VII & Core & Histona \\
\hline VIII & Peptídeo associado ao hexon & Estabilização \\
\hline IX & Peptídeo associado ao hexon & Estabilização \\
\hline$X(\mu)$ & Core & Desconhecida \\
\hline $\mathrm{TP}$ & Genoma & Replicação do DNA \\
\hline
\end{tabular}

Três proteínas do capsídeo viral são mais expostas ao ambiente: hexon, penton-base e fibra. Juntas, estas proteínas mediam a interação do adenovírus com o sistema celular do hospedeiro durante os passos iniciais da infecção, sendo alvos da ação de anticorpos neutralizantes e inibidores de hemaglutinação.

\section{$1.4 \mathrm{O}$ genoma dos Adenovírus}

O genoma dos adenovírus é composto por fita dupla de DNA linear, com 36Kb. Suas extremidades contêm ITRs, ou sequências invertidas repetidas, que podem variar de 100 a 140 pb. Existem duas origens idênticas para replicação do DNA, uma em cada repetição terminal (Bënko e Harrach, 2003; Shenk, 2001). No genoma viral existem oito unidades de transcrição dependentes da RNA polimerase II. Cinco unidades são de transcrição precoce 
(E1A, E1B, E2, E3, E4), duas unidades de transcrição intermediária (pIX e PIVa2) e, uma unidade de transcrição tardia principal (MLTU- Major Late Transcription Unit) que processa cinco famílias de mRNA (L1, L2, L3, L4, L5). O genoma viral possui ainda um ou dois genes VA-RNA (dependendo da espécie) transcritos pela RNA polimerase III (Kidd et al., 1995; Shenk, 1996). A figura 3 apresenta a representação esquemática do genoma adenoviral.

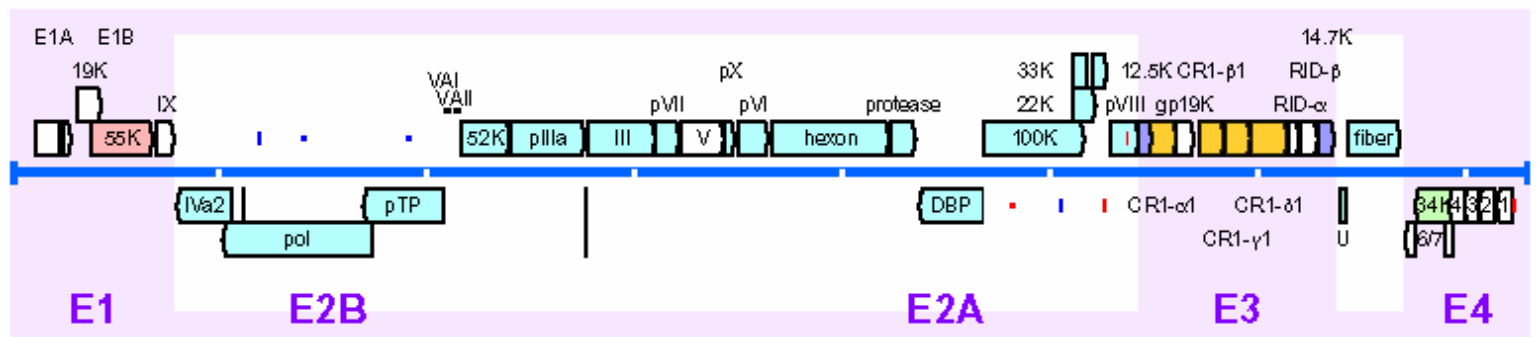

Figura 3 - Representação esquemática do genoma dos adenovírus, suas regiões de transcrição e genes. Modelo: Mastadenovirus SadV-25 (HAdV-E) (Davison et al., 2003).

A expressão das proteínas do genoma adenoviral pode ser dividida em três fases: precoce, intermediária e tardia. Na fase precoce são expressos genes que modulam as funções celulares, facilitando a replicação do DNA viral e a transcrição dos genes tardios. As duas fitas do DNA viral são transcritas. Na fita, em que a transcrição ocorre da direita para a esquerda, são trasncritos: E1A, E1B, IX, MLTU, VA-RNA e E3. Na fita complementar, cuja transcrição ocorre da esquerda para direita, são transcritos: E4, E2 e IVa2 (Shenk, 1996). A figura 4 apresenta os genes transcritos pelas duas fitas do DNA adenoviral.

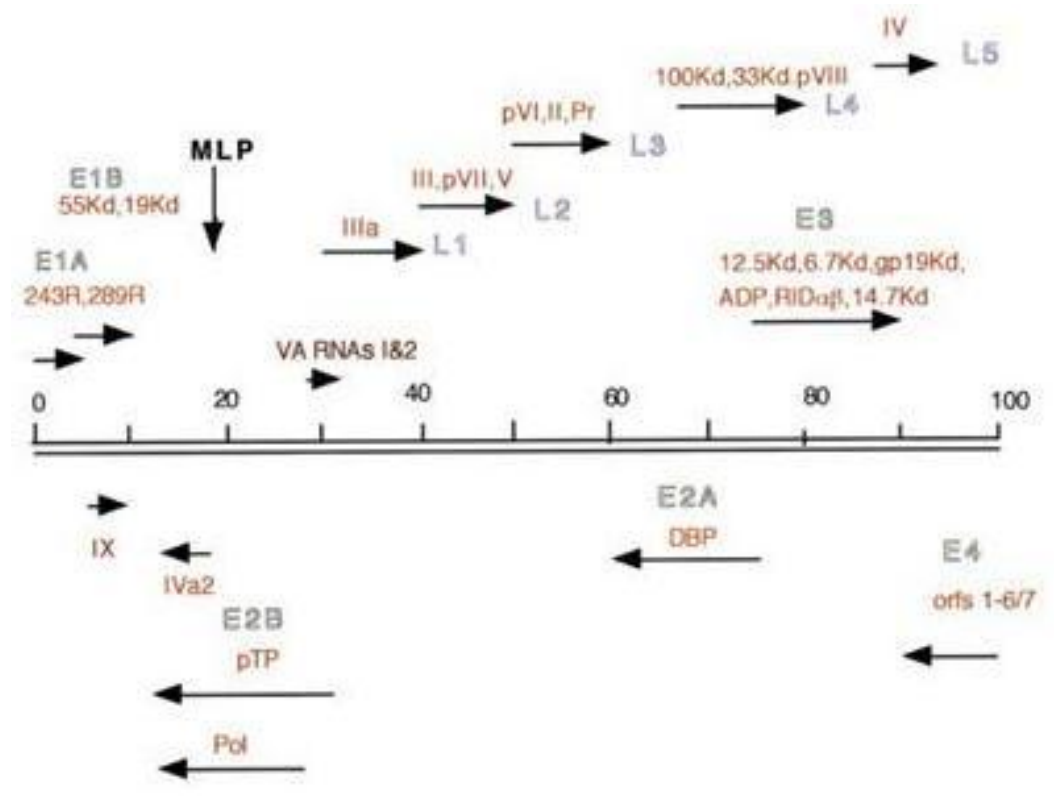

Figura 4 - Transcrição do genoma dos adenovirus. As setas indicam a direção da transcrição (Russell, 2000). 


\subsubsection{Unidades de transcrição precoce}

\subsubsection{Região E1A}

Os genes da região E1A são os primeiros a serem expressos durante a infecção pelos adenovírus humanos. A região E1A codifica duas proteínas, E1A-289R e E1A-243R que possuem papel importante na infecção produtiva e na transformação celular. Estas proteínas modulam o metabolismo celular fazendo com que a célula fique mais susceptível à replicação viral (Russel, 2000). Elas induzem a célula infectada a entrar na fase S do ciclo celular, sendo considerada por muitos autores como um oncogene (Cao et al., 2007; Nevels e Dobner, 2007; Takahashi et al., 2007). Para isso, genes da região E1A se ligam ao pRB (proteína do retinoblastoma), liberando o fator de transcrição E2F. Este, por sua vez, ativa genes celulares, ocorrendo a progressão do ciclo celular (fase G1 - fase S) e favorecendo um ambiente ideal para a replicação do DNA viral (Shenk, 1996).

Além disso, seus genes trans-ativam todos os outros genes adenovirais e promovem a expressão de alguns genes celulares, interferindo no processo de divisão celular e na regulação do $\mathrm{NK}_{-\mathrm{k} \beta}$ (Fator de Necrose Tumoral) e da proteína p53 (Russel, 2000) .

\subsubsection{Região E1B}

A região gênica E1B codifica polipeptídeos necessários ao ciclo lítico do vírus, replicação do DNA viral e que bloqueiam a apoptose (Frisch e Mymryk, 2002; Hortwitz, 1996). Duas proteínas são codificadas nesta região: 19K e 55K. Ambas proteínas têm capacidade de bloquear a apoptose celular, porém, de forma distinta: A proteína $55 \mathrm{~K}$ inibe a apoptose mediada por p53 (Zhao e Liao, 2003). A proteína p53 é um supressor tumoral que regula a transcrição de diversos genes envolvidos no ciclo celular e apoptose. Para este bloqueio, a 55K, juntamente com a E4ORF6, formam um complexo que promove a degradação de p53 nos proteassomos (Harada et al., 2002).

A proteína $19 \mathrm{~K}$ é análoga ao Bcl-2. Este é um importante inibidor da apoptose induzida por estímulos variados, como Fas, fator de necrose tumoral (TNF- $\alpha$ ) e apoptose dependente de p53 (Chiou et al., 1994; Gooding et al., 1991; Russel, 2000). Ambas as proteínas são requeridas para conter a apoptose celular ativadas pelas proteínas das regiões E1A e E4 (Russel, 2000). 


\subsubsection{Região E2}

Os produtos gênicos da região E2 são subdivididos em E2A (DBP) e E2B (pTP e Pol). Estas três proteínas são necessárias para replicação do DNA viral e subsequente transcrição de genes tardios (Russel et al., 2000). A DNA polimerase (Pol) é uma das proteínas mais conservadas entre os sorotipos de adenovírus (Ikeda et al., 1981). Esta proteína pertence a família Pol (DNA polimerases que têm a atividade 3'5'exonuclease) (Field et al., 1984).

A DNA binding proteín (DBP) é uma proteína ATP independente de alta afinidade por DNA de fita simples. Esta proteína desestabiliza a hélice de DNA durante sua elongação e replicação (Liu et al., 2003). A proteína terminal, TP, se liga covalentemente à extremidade 5'do DNA viral, atuando como origem de replicação. A TP forma um heterodímero com a DNA polimerase necessário para o início da replicação do DNA viral. Além disso, esta proteína tem como função proteger o DNA viral de exonucleases e mediar sua ligação à matrix nuclear (Roovers et al., 1993; Schaack et al., 1990; Webster et al., 1994).

\subsubsection{Região E3}

O tamanho e composição das unidades transcritas pela região E3 não é conservado, e varia, consideravelmente, entre adenovírus das diferentes espécies (Kajon et al., 2005). Nos adenovírus da espécie $\mathrm{F}$, essa região possui aproximadamente 3000 pb enquanto, nos adenovírus da espécie D, 5200 pb. As variações desta região são observadas também com relação à diferentes números de regiões codificantes, por exemplo, adenovírus da espécie $\mathrm{F}$ possuem somente 5 regiões abertas de leitura (ORFs), adenovírus D têm 8, subgrupo B1 (sorotipos 3 e 7) têm 9 ORFs (Burgert e Blusch, 2000).

Alguns dos genes da E3 estão presentes nos adenovírus de todas as espécies (codificantes das proteínas $10.4 \mathrm{~K}, 14.5 \mathrm{~K}$ e $14.7 \mathrm{~K}$ ), outros estão presentes na maioria das espécies (12.5k: espécies A-E; 19K: espécies B-E) e, alguns, parecem ser espécie específica (29.4K e 30.7K da espécie A). Três das proteínas codificadas pelo gene E3 (10.4K, 14.5K e 14.7K) são funcionalmente conservadas entre os adenovírus (Burgert e Blusch 2000; Horwitz, 2001, 2004).

A figura 5, apresenta a organização gênica da região E3 das 6 espécies de adenovírus humanos. 


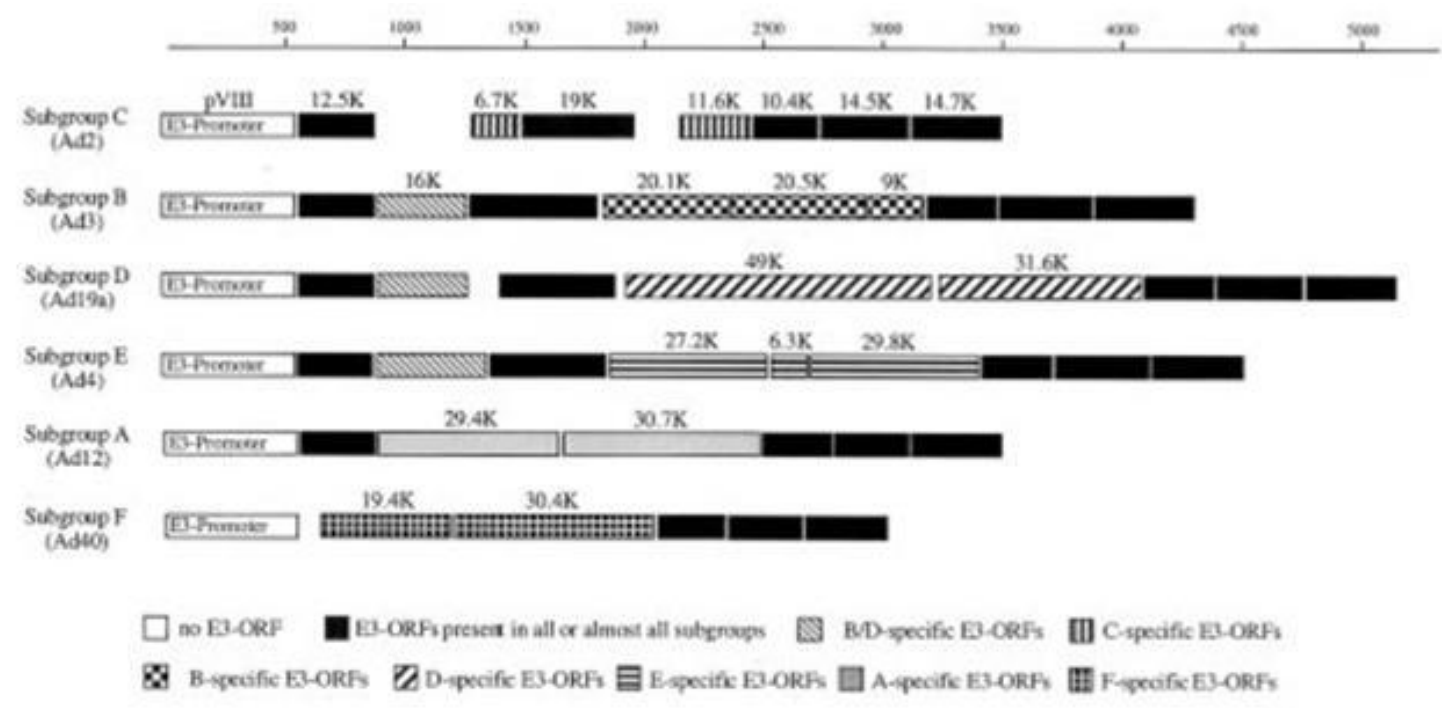

Figura 5 - Organização gênica da região E3 dos adenovírus das espécies A-F (Burgert e Blusch, 2000).

As proteínas codificadas pela região E3 possuem função imunorregulatória, não sendo necessárias para a replicação do adenovírus em culturas celulares e, por este motivo, muitos vetores adenovirais são desprovidos destes genes. (Gonçalves e de Vries, 2006; Lichtenstein et al., 2004; Windhein et al., 2004). Entretanto, in vivo os produtos do gene E3 têm a função de modular a resposta imune do hospedeiro (Fessler et al., 2004).

A proteína $12.5 \mathrm{~K}$, codificada por todas as espécies de adenovírus, exceto espécie $\mathrm{F}$, é bastante conservada e possui função ainda desconhecida. Alguns estudos demostraram que a deleção do gene que codifica esta proteína não afeta o crescimento viral nas culturas celulares (Hawkins e Wold, 1992).

A $19 \mathrm{~K}$ é a proteína mais abundante de região E3 e é codificada por quase todos adenovírus humanos com exceção das espécies A e F. Esta proteína tem a propriedade de se ligar ao Complexo Maior de Histocompatibilidade (MHC-I), retendo-o no retículo endoplasmático, impedindo assim a exposição de peptídeos virais na superfície celular e a lise das células infectadas pelos linfócitos $\mathrm{T}$ citotóxicos (Persson et al., 1980). In vivo, foi observado que pulmões de ratos infectados com adenovírus da espéci $\mathrm{C}$, do tipo selvagem apresentam uma imunopatologia menos severa do que os animais infectados com mutantes cuja ORF 19K foi deletada (Ginsberg et al., 1989).

A proteína $16 \mathrm{~K}$, expressa pelos HAdV-B e E, é pouco estudada. Esta proteína possui a mesma localização genômica da proteína $6.7 \mathrm{~K}$ (espécie C) e ambas possuem homologia na região C-terminal; isto sugere que possam ter função similar durante a infecção (Hawkins et al., 1995). A proteína 6.7K parece estar envolvida no bloqueio da apoptose celular. 
(Lichtenstein et al., 2004). Estudos "in vitro" observaram que adenovírus mutantes com a ORF 16K deletada têm replicação igual ao vírus selvagem (Hawkins et al., 1995).

As proteínas $20.1 \mathrm{~K}$ e $20.5 \mathrm{~K}$ são exclusivas dos adenovírus espécie B e não possuem função estabelecida. Estudos mostram a síntese destas proteínas em células infectadas pelos adenovírus 3 e 7, que são encontradas expressas na membrana das células infectadas, e não no citoplasma (Howkins e Wold, 1995).

A proteína 7.7K é codificada pelos adenovírus da subespécie B1 (sorotipos 3, 7, 16, 21). Esta ORF apresenta um grande variação em seu tamanho e na sequência nucleotídica, sendo $7.7 \mathrm{~K}$ nos adenovírus $7 \mathrm{p}$ e $9.0 \mathrm{~K}$ nos adenovírus $3 \mathrm{p}$, e encontrando-se ausente nos adenovírus subespécie B2 (Kajon et al., 2005).

As proteínas $14.7 \mathrm{~K}, 10.4 \mathrm{~K}$ e $14.5 \mathrm{~K}$ protegem as células infectadas do Fator de necrose tumoral e da apoptose mediada por Fas (Krajcsi et al., 1996). A 10.4K junto com a 14.4K formam um complexo chamado RID (Receptor de Internalização e Degradação) que induz a internalização e degradação dos receptores de morte celular situados na membrana celular, tais como: Fas, TRAIL-R1 e R2, impedindo a interação destes receptores aos seus ligantes (Tollefson et al., 1990).

A proteína $11.6 \mathrm{~K}$, também chamada de ADP (adenovirus death protein ou proteína de morte dos adenovírus) é uma das proteínas da região E3 que é expressa tardiamente, sob ação do MLP (major late promotor) (Tollefson et al., 1996). Esta proteína transmembrânica nuclear é expressa somente pelos adenovírus da espécie $\mathrm{C}$, sendo relacionada à lise celular (Tollefson et al., 1996).

\subsubsection{Região E4}

A região E4 é altamente conservada e possui similaridade organizacional em todos os sorotipos de adenovírus. Esta região codifica em torno de 6 polipeptídeos, denominados de acordo com sua ORF (de 1-6/7). Somente a deleção das ORFs 3 e 6 produz uma multiplicação viral defectiva em culturas celulares sendo, consequentemente, as mais estudadas (Bridge e Ketner, 1989; Huang e Hearing, 1989). Estas ORFs formam um complexo com a proteína $55 \mathrm{~K}$, codificada pela região E1B, aumentando a taxa de replicação viral e a síntese das proteínas tardias (Leppard e Everett, 1999). Estas proteínas também inibem a atividade da proteína quinase DNA dependente (DNA-PK), a qual é essencial para o funcionamento do sistema de reparo de DNA. 
O papel das ORFs 1-2 permanece desconhecido. A ORF 4 parece inibir a transdução de genes virais e celulares e também induz a apoptose celular independente de p53, principalmente em células transformadas (Kleinberger e Shenk, 1993; Kleinberger, 2000; Mannervik et al., 1999).

\subsubsection{RNAs associados aos vírus (VA-RNA)}

Os VA-RNAs são pequenos RNAs de fita dupla, transcritos pela RNA polimerase III (Kidd et al., 1995). Dependendo da espécie de adenovírus podemos encontrar 1 ou 2 VARNAs: As espécies A, F e B2 possuem apenas um gene VA-RNA (VA-RNAI), enquanto as espécies B1, C e E possuem dois genes (VA-RNAI e II) (Kidd et al., 1995).

A função do VA-RNA I é estabelecida. Estes RNAs se ligam à enzima PKR (proteína quinase dependente de RNA), antagonizando assim, o seu efeito. Este processo resulta no efeito abortivo do mecanismo de defesa anti-viral induzido por IFN (Katze et al., 1987; Kitajewski et al., 1986).

A função da VA-RNA II permanece deconhecida.

\subsubsection{Região de transcrição intermediária}

Os genes de transcrição intermediária são expressos imediatamente após a replicação do DNA viral e antes do início de expressão dos genes tardios. São expressas duas proteínas multifuncionais nesta região (pIX e pIVa2), sendo estas, transcritas por promotores independentes (Binger e Flint, 1984).

A polipeptídeo IX é a menor proteína do capsídeo viral. Esta proteína somente aparece nos adenovírus do gênero Mastadenovirus. Junto com a proteína hexon, a pIX forma um complexo estável que age estabilizando o capsídeo viral e também auxiliando no empacotamento do DNA viral (Ghosh-Choudhury et al., 1987; Vellinga et al., 2005). Além disso, a expressão da proteína IX parece estimular a atividade de certos promotores, como das regiões E1A e E4 (Vellinga et al., 2005).

O polipeptídeo IVa2 possui propriedade transativadora para MLP (Major Late Protein) (Tribouley et al., 1994). Esta proteína parece ser necessária ao início da montagem das partículas virais, pois partículas defectivas vazias ou incompletas podem ser isoladas de 
células infectadas com adenovírus deletados neste polipeptídeo (Ostapchuk et al., 2005; Zhang et al., 2001; Zhang e Imperiale, 2003).

\subsubsection{Unidade de transcrição tardia}

A unidade de transcrição tardia é controlada pela MLP. Esta região ocupa aproximadamente $40 \%$ do genoma viral e codifica todas as proteínas estruturais, exceto a pIX. A transcrição desta região ocorre primeiramente com a formação de um único transcrito primário, denominado Major Late Transcript Unit (MLTU), que recebe de 5 a 6 diferentes sítios de poliadenilação e, após splicing alternativo, processa 5 superfamílias de mRNAe proteínas estruturais sendo: LI: proteínas IIIa; L2: proteínas III, VII, V; L3: proteínas pentonbase,VI; hexon, protease 23K; L4: proteína VIII e L5: proteina fibra (Mei et al., 2003; Young, 2003).

A ativação da MLP parece requerer fatores de transativação cis e trans, como por exemplo, as proteínas de expressão intermediária pIVa2 e pIX (Binger e Flint, 1984; Young, 2003).

Durante a fase tardia do ciclo celular, os mRNAs são traduzidos e os polipeptídeos virais são imediatamente liberados dos poliribossomos e transportados ao núcleo para a formação da partícula viral. No interior do núcleo, ocorrem as seguintes etapas: formação do capsômero, formação do capsídeo e incorporação do DNA viral no seu interior (Russel, 2000).

\subsection{Entrada do vírus na célula e replicação viral}

O ciclo infectivo dos adenovírus é claramente dividido em duas fases. A primeira, chamada precoce, corresponde à entrada do vírus na célula hospedeira, passagem do genoma viral para o núcleo celular e a transcrição e expressão dos genes precoces. Estes eventos precoces modulam as funções celulares para facilitar a replicação do DNA viral e a transcrição e expressão dos genes tardios (Russel, 2000). Essa fase, em células permissívas, dura aproximadamente de 6-8 horas.

A entrada do vírus na célula envolve uma alta afinidade da região globular C-terminal da fibra com o receptor celular primário, denominado CAR (Coxsackie/adenovirus receptor) (Bergelson et al., 1997; Chroboczek et al.,1992; Louis et al., 1994) . Após interação da fibra 
com o receptor celular, a entrada do vírus ocorre por endocitose mediada por clatrinas. Para essa internalização, o motivo RGD, da proteína penton-base, é exposto e interage com integrinas $\alpha v \beta 3$ e $\alpha v \beta 5$ presentes na membrana celular (Mathias et al., 1994; Russel, 2000).

Após a internalização, os adenovírus são desmontados, e as fibras são liberadas, ocorrendo a exposição da penton-base (Greber et al., 1996). Com a acidificação do endossomo, $\mathrm{pH}$ 6.0, a penton-base sofre mudanças conformacionais, expondo domínios hidrofóbicos, os quais interagem com a membrana do endossomo, ocorrendo assim a sua ruptura e o escape dos vírus (Seth et al., 1994).

O transporte dos adenovírus pelo citoplasma até o núcleo celular parece ser mediado pela associação do core viral com a proteína celular p32 (Matthews e Russel, 1998). A p32 é uma proteína primariamente localisada nas mitocondrias mas também pode ser detectada no núcleo celular. Estudos têm sugerido que esta proteína é um componente de transporte do sistema celular e que o vírus pode capturar para a ecessar o núcleo da célula (Russel et al., 2000). Esta passagem para o núcleo é relativamente rápida e acontece através do transporte ativo de corpos sobre os microtúbulos por intermédio de proteínas motoras como a dineina (Leopold et al., 2000; Russel, 2000; Suomalainen et al., 1999).

A entrada no núcleo é mediada pela interação da proteína hexon com proteínas do complexo do poro nuclear (CAN/Nup214) que ancoram a partícula viral ao poro nuclear, iniciando o desnudamento (Trotman et al., 2001). Estudos demonstraram que partícula virais podem ser detectadas na membrana nuclear, após 1 hora do início da infecção (Dales e Chardonett, 1973). O DNA viral e as proteínas V e VII podem ser detectados no núcleo entre 1 e 2 horas após infecção (Greber et al., 1997; Matthews e Russell, 1998; Russel, 2000).

A figura 6 apresenta o esquema da via de infecção dos adenovírus em células permissivas. 


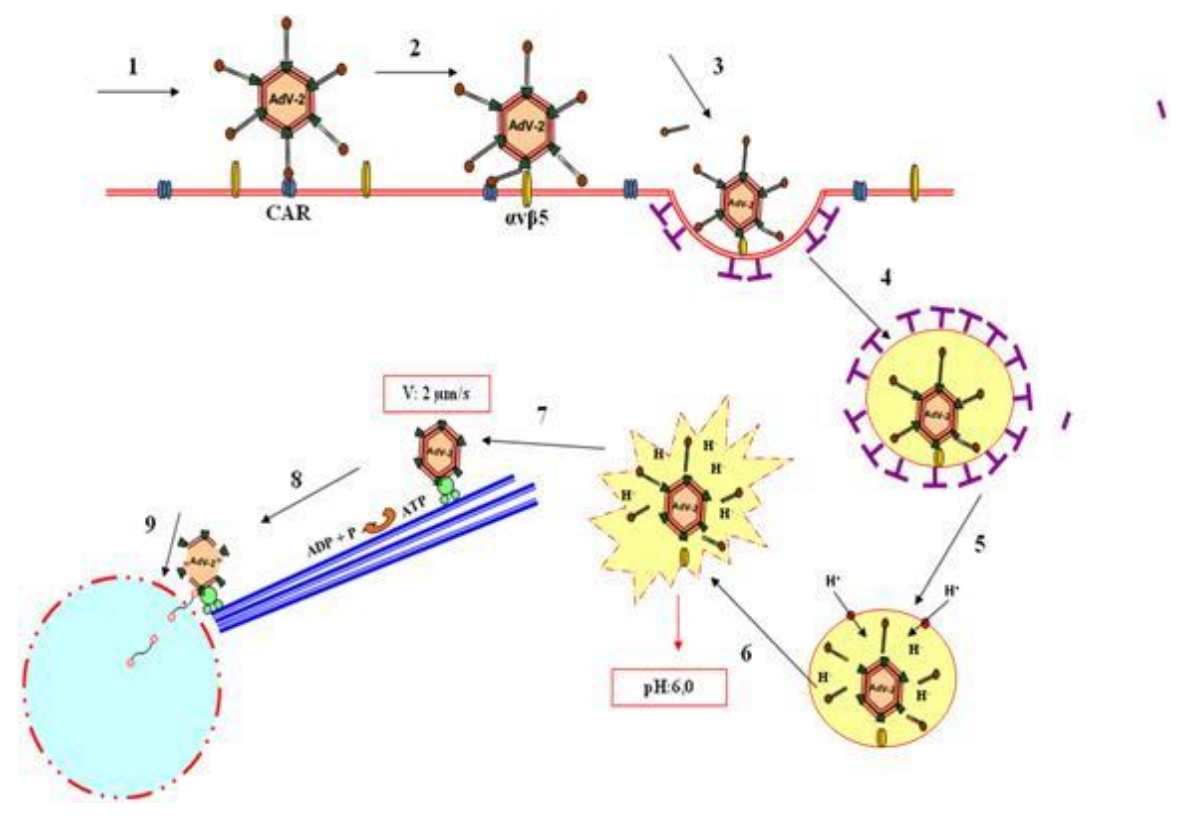

Figura 6: Esquema da via de infecção do adenovírus. (1) Reconhecimento do CAR pela região globular da fibra; (2) Reconhecimento das integrinas pela penton-base; (3) Formação da fossa revestida por clatrina ; (4) Endocitose do adenovírus com formação da vesícula revestida por clatrina; (5) Liberação das fibras do adenovírus e acidificação do endossomo; (6) Lise do endossomo devido à interação da penton-base com a membrana; (7) Transporte do capsídeo pela dineína migrando sobre o microtúbulo; (8) Interação do capsídeo com proteínas do poro nuclear; (9) Liberação do core no poro nuclear (Modificado de Medina-Kauwe, 2003 por Siqueira-Silva, 2008).

Assim que o core viral penetra no núcleo é direcionado à matriz nuclear onde a TP forma um complexo com a proteína celular CAD (enzima de síntese de pirimidina) e, possivelmente, com outras proteínas presentes na matrix nuclear (Angeletti e Engler, 1998; Fredman e Engler, 1993).

O DNA dos adenovírus contém regiões terminais repetitivas, chamadas ITRs, que estão associadas à TP covalentemente à terminação 5'do DNA viral (Rekosh et al., 1977). A replicação do DNA viral começa em ambas as terminações 5'do genoma, onde sequências internas à ITR (5'-ATAATATACC-3') são reconhecidas pelo heterodímero formado pela pTP e DNA polimerase (Hay et al., 1995).

Para o início da replicação do DNA viral são necessários os fatores celulares NF I e NF III. Os fatores celulares NF I se ligam à DNA polimerase e à pTP, recrutando este complexo (pTP-DNA polimerase) para a origem de replicação; o NF III estabiliza a fita de DNA (Verrijzer et al., 1991). A seguir, a DNA polimerase celular adiciona um monofosfato de citosina $\left(3^{\prime} \mathrm{OH}\right)$ à pTP, funcionando como um primer para a DNA polimerase (Shenk, 1996). Após a adição de mais nucleotídeos na nova fita de DNA, a DNA polimerase se separa da pTP (King et al., 1997). 
A cadeia de elongação requer duas proteínas virais codificadas pela região E2 (a polimerase viral e a DNA binding protein) e o fator celular NF II (Shenk, 1996). A DNA binding protein desempenha a função de estabilizar a hélice do DNA durante a sua elongação e replicação, facilitando assim a função da polimerase.

A transcrição dos genes tardios somente se inicia após a replicação do DNA. A maior parte dos mRNAs tardios individuais é produzida a partir de um grande transcrito (MTLU), o qual é codificado pelo filamento direito do genoma viral, sendo processado posteriormente em mRNAs individuais.

As proteínas do capsídeo são produzidas no citoplasma celular e, em seguida, transportadas para o núcleo, ocorrendo assim a montagem das novas partículas virais nos corpos de inclusão nucleares. Os hexons se agrupam formando as faces do icosaédro. O DNA viral penetra no capsídeo vazio através de uma abertura em um dos vértices. Por fim, os pentons (base e fibra) fecham a partícula viral (Ostapchuk e Hearing, 2003).

A montagem da progênie viral é acompanhada da alteração da permeabilidade da membrana nuclear, sendo necessária para que ocorra a liberação dos vírus recém formados para o citoplasma (Tollefson et al., 1996) e posterior desintegração da membrana plasmática e liberação dos vírus da célula (Russel, 2000). O processo de lise celular, induzida pelos adenovírus, encontra-se bem descrito para os adenovírus da espécie C, porém o mesmo processo não pode ser aplicado a todas as espécies de adenovírus (Siqueira-Silva et al., no prelo 2009).

\subsection{Resposta do hospedeiro à infecção por adenovírus}

Durante a infecção por adenovírus, uma rápida resposta imune é induzida. Esta resposta ocorre como resultado da interação do vírus com a célula infectada e parece não ser dependente da transcrição de algum gene viral. Inicialmente a resposta desencadeada varia de acordo com o receptor e tipo de célula infectada, levando a uma complexa sinalização em cascata com diferentes resultados, como por exemplo, produção do fator de transcrição do NF-kB e interferon (Randall e Goodbourn, 2008; Russel, 2009).

Muruve (2004) descreve que somente a interação do capsídeo viral com a célula hospedeira é suficiente para desencadear uma resposta inflamatória. $\mathrm{Na}$ infecção de adenovírus sorotipo 5, em células epiteliais de pulmão (A549), somente a fibra é suficiente para induzir uma resposta inata pro-inflamatória (Tamanini et al., 2006). 
A resposta imunológica adaptativa do hospedeiro, seja ela celular ou humoral, esta relacionada ao hexon viral. $\mathrm{O}$ hexon possui sete regiões hipervariáveis e, algumas delas, parecem funcionar como antígenos para anticorpos neutralizantes definindo então, os sorotipos. (Madisch et al., 2005; Sumida et al., 2005; Wu et al., 2004). Alguns trabalhos apontam para a importância da fibra e da penton-base para a indução de anticorpos neutralizantes (Hong et al., 2003; Stallwood et al., 2000). Gahery-Segard et al., (1998) demostraram a importância dos anticorpos anticapsídeo viral para neutralização.

A resposta imune celular para os adenovírus é basicamente efetuada por linfócitos $\mathrm{T}_{\mathrm{CD} 8}$ e $\mathrm{T}_{\mathrm{CD} 4}$ (Leen et al., 2004; Russel, 2000). Os linfócitos citotóxicos ( $\mathrm{T}_{\mathrm{CD} 8}$ ) atuam após exposição do antígeno viral (hexon) com MHC classe I (Molinier-Frenkel et al., 2002; Russel 2000). Esse processo libera perforinas, resultando em lise celular.

Os linfócitos $\mathrm{T}_{\mathrm{CD} 4}$ são importantes na montagem de uma resposta proliferativa à infecção viral (Russel, 2000). Esta resposta parece ser mediada pela apresentação do epítopo viral pelo $\mathrm{MHC}$-II. As células $\mathrm{T}_{\mathrm{CD} 4}$ estimulam, também, a proliferação dos linfócitos $\mathrm{B}$, fornecendo imunoglobulinas para a resposta celular humoral.

\subsection{Epidemiologia dos adenovírus humanos}

Os adenovírus humanos (HAdV) estão associados a diferentes doenças, em adultos e crianças, como: infecções respiratórias, gastrentéricas, urinárias, oculares e doenças no sistema nervoso central (Adhikary et al., 2004; Ebner et al., 2006; Erdman et al., 2002). Estes vírus têm sido frequentemente associados a infecções generalizadas em pacientes imunocomprometidos, como transplantados (Hierholzer, 1992; Ison, 2006). Os adenovírus são transmitidos por contato direto pessoa a pessoa, por via respiratória ou por via fecal-oral, através de água e alimentos contaminados. Alguns sorotipos de adenovírus possuem baixa patogenicidade, sendo associados à infecções assintomáticas.

Os adenovírus da espécie $\mathrm{A}$, sorotipos 12, 18 e 31 são associados à infecções entéricas pouco frequentes em crianças menores de 1 ano de idade. Estudos demonstraram que os sorotipos destas espécies têm alta capacidade transformante em células de hamsters recémnascidos, porém, não há descrições de associação destes vírus com tumores em humanos (Wadell, 1984).

A análise de restrição do DNA permitiu a divisão dos adenovírus da espécie B em duas subespécies: B1 e B2. Na subespécie B1 encontram-se os sorotipos 3, 7, 16, 21 e 50, 
frequentemente associados a casos de infecção respiratória aguda (IRA) e às infecções oculares. O sorotipo 7, seguido pelo 3, são os mais frequentemente isolados de casos de IRA no Brasil e estão associados a casos graves como bronqueolites, pneumonias e óbitos. As infecções causadas pelo sorotipo 7 podem variar de uma leve doença no trato respiratório superior e conjuntivites até grave doença no trato respiratório inferior, disseminação para outros orgãos e morte, principalmente em crianças.

Na subespécie B2 encontram-se os sorotipos 11, 14, 34 e 35. Estes sorotipos são associados a casos de infecções renais e no trato urinário sendo, frequentemente, isolados de pacientes submetidos a transplantes renais de imunocomprometidos (DeJong et al., 1999; Russel, 2009). Adenovírus sorotipo 14 foram relacionados a surtos graves de IRA nos Estados Unidos nos últimos anos (Lewis et al., 2009; Tate et al., 2009).

Os adenovírus da espécie C, sorotipos 1, 2, 5 e 6 são considerados endêmicos, infectando adenoides e tonsilas e apresentando alta incidência em crianças menores de cinco anos de idade (Horwitz, 1996). As infecções causadas por estes sorotipos representam mais do que a metade de todos os adenovírus isolados no mundo (59\%), sendo os principais sorotipos isolados o 1 (34,3\%), o 2 (42,8\%) e o 5 (18,6\%) (Adhikary et al., 2004; Horwitz, 1996).

A espécie D apresenta a maior variabilidade genética incluindo um grande número de sorotipos: 8-10, 13, 15, 17, 19, 20, 22-30, 32, 33, 36-39, 42-49 e 51. A maioria destes sorotipos são raramente isolados, sendo as exceções os sorotipos 8, 19a e 37, os quais são associados a surtos de ceratoconjuntivite epidêmica (Russel et al., 2009). De Jong et al. (1981) descreveram que o sorotipo 37 pode ser transmitido por via sexual e, em 1999 o isolamento do sorotipo 51 em pacientes com AIDS.

A espécie E possui apenas um sorotipo humano, 4. Este sorotipo é responsável por surtos de infecção respiratória em recrutas militares nos Estados Unidos (Metzgar et al., 2005). Wadell (1984) apresenta a associação deste sorotipo com conjuntivites. O sorotipo 4 pode ser isolado de casos de conjuntivite e de infecções respiratórias.

Os sorotipos da espécie F, 40 e 41 possuem tropismo entérico e são considerados de grande importância na etiologia da gastrenterite infantil (Tiemessen e Kidd, 1995). Estes vírus apresentam características biológicas, moleculares e estruturais diferentes dos demais adenovírus, como por exemplo a presença de duas fibras (Kidd et al., 1993).

Um novo sorotipo de adenovírus, classificado como 52, foi isolado de pacientes com gastrenterites no ano de 2007. Esse sorotipo, embora apresente algumas características morfológicas semelhantes aos adenovírus espécie F, como a presença de duas diferentes 
fibras, e o tropismo pelo epitélio intestinal, ainda não foi enquadrado em nenhuma das seis espécies conhecidas. Filogeneticamente os adenovírus 52 são similares ao adenovírus isolados de macacos, sorotipo 1 (SAdV-1 - Simian Adenovirus serotype 1) (Jones II et al., 2007).

\subsubsection{Adenovírus humanos em infecções respiratórias}

As infecções respiratórias agudas (IRA) são consideradas uma das maiores causas de morbidade e mortalidade em todo mundo, sendo responsáveis pela morte de quatro milhões de pessoas por ano (World Health Statistics, 2008). Segundo dados da Fundação Seade, desde o ano 2000, as infecções do aparelho respiratório são a $3^{\text {a }}$ causa de óbitos na infância, superadas apenas pelas doenças congênita e perinatais. Dados fornecidos pelo DATASUS, referentes ao estado de São Paulo, mostram que de janeiro de 2006 a janeiro de 2007, foram computadas 68.921 internações por pneumonias e 20.659 em decorrência de doença asmática.

Os vírus são os principais agentes etiológicos causadores das IRA, responsáveis por 45 a $60 \%$ de todas as doenças respiratórias em crianças. O vírus sincicial respiratório (HRSV), o rinovírus (HRV) e os adenovírus (HAdV) são os mais frequentes (Canducci et al., 2008).

Os adenovirus humanos representam 5 a $15 \%$ dos vírus isolados de crianças menores de 2 anos de idade com IRA (Moura et al., 2007). Crianças com doença respiratória causada por adenovírus apresentam uma vasta variedade de sintomas incluindo faringites, inflamações nas tonsilas, febre faringo-conjuntival, bronquiolites e pneumonias (Palomino et al., 2000; Vieira et al., 2001). As pneumonias em crianças têm sido frequentemente associadas aos sorotipos 3 e 7 (espécie B) e, ocasionalmente, a doença é fatal (Kajon et al., 1996; Straube et al., 1983).

As infecções respiratórias causadas por adenovírus acometem, também, jovens e adultos. Epidemias de infecções por HAdV têm sido descritas desde a década de 50 em recrutas militares na America do Norte (Hillerman e Webner, 1954). Estas epidemias começaram a ser controladas com a introdução de vacinas para os sorotipos 4 e 7, na década de 70, porém, em 1996, a vacinação foi descontinuada e novos surtos de IRA em recrutas foram evidenciados (Gray et al., 2000). Para monitorar os efeitos da não vacinação, semanalmente, vigilantes acompanhavam os casos de IRA em campos de recrusão militar. Durante os inverno de 1997-1998, as infecções por adenovírus foram responsáveis por mais de $90 \%$ das IRA, sendo isolados os sorotipos 3, 4, 7 e 21 (Gray et al., 2000). 
No Brasil, os principais sorotipos de adenovírus, relacionados a casos de IRA, são os da espécie C (1, 2, 5 e, menos frequentemente 6) e da espécie B, sorotipos 3 e 7 (Moura et al., 2007; Santos, 2007). Nos Estados Unidos, estes mesmos sorotipos de adenovírus se alternam durante os anos, porém, mais recentemente ocorreram casos fatais com os sorotipos 11, 14 e 21 (Gray et al., 2007; Laham et al., 2008; Metzgar et al., 2007). É interessante ressaltar que estes três sorotipos ainda não foram detectados em amostras coletadas no Brasil.

Desde que a linhagem Gomen (protótipo do sorotipo 7) foi isolada em 1958, diferentes tipos genômicos do HAdV-7 têm sido identificados (Kajon et al., 2005; Li e Wadell, 1986; Wadell et al., 1985). De todos os variantes deste sorotipo, o tipo genômico $7 b$ têm sido o mais frequente na Europa, America do Norte e do Sul. No Brasil, durante muitos anos, o variante $7 \mathrm{~b}$ foi o mais detectado (Moraes et al., 1997). O tipo genômico $7 \mathrm{~h}$ foi primeiramente isolado em paises do Cone Sul (Argentina Uruguai e Chile) e é considerado o mais patogênico (Kajon et al., 1994). Posteriormente este mesmo variante foi detectado de amostras coletadas no Japão e na cidade de São Paulo (Moura et al., 2007; Tanaka et al., 2000).

\subsection{Métodos de detecção e caracterização dos adenovírus}

O diagnóstico laboratorial das infecções causadas pelos HAdV normalmente é realizado através de métodos rápidos de detecção como o ensaio imunoenzimático (ELISA) e a reação de imunofluorescência indireta. Ambos os métodos permitem a detecção direta do vírus no material clínico, utilizando para isso, antisoros comuns ao gênero, porém não distinguem os sorotipos. Ambas técnicas são de baixo custo e fácil execução mas apresentam baixa sensitividade (Barenfanger et al., 2000; Raty et al., 1999). A imunofluorescência indireta, embora utilizada em diferentes estudos para detecção de vírus respiratórios, já foi demostrada por ter baixa sensibilidade na detecção dos adenovírus, ficando muito aquem do cultivo e do diagnóstico molecular (Raty et al., 1999; Sanalios, 2004).

O isolamento viral nas culturas celulares é considerado o sensível para detecção de adenovirus, no entanto, este método é demorado, levando no mínimo quinze dias para se obter o isolamento. Alguns adenovírus são de difícil cultivo e por isso, o isolamento deve ser feito em duas ou três linhagens celulares diferentes. O diagnóstico laboratorial por cultivo não permite um retorno imediato ao paciente e, em estudos com grande número de amostras clínicas torna-se inviável. A partir do isolamento viral em culturas celulares é possível 
caracterização sorotípica dos adenovírus feita po meio da reação de neutralização, utilizando soros policlonais sorotipo-específicos.

Para caracterização genotípica de adenovírus humanos utiliza-se a técnica de restriction fragment length polymorphism - RFLP (Wadell et al., 1980). Esta técnica consiste na extração do DNA viral, a partir dos vírus purificados de células infectadas e sua restrição com uma coleção de 10 a 12 endonucleases. Com esta técnica, variações distribuídas ao longo do genoma dos vírus podem ser observadas, porém, essas variações não refletem alterações sorológica e, a expressão destas mutações "in vivo" não pode ser inferida (Wadell et al., 1980).

A reação em cadeia da polimerase (PCR) permite a detecção viral a partir da amplificação de um pequeno número de cópias do material genético. Esta técnica é rápida e sensível, possibilitando o diagnóstico laboratorial direto na amostra clínica (Raty et al., 1999; Sanalios, 2004). Dependendo da região do DNA amplificada pela PCR é possível a distinção entre espécies e sorotipos (Lu e Erdman, 2006; Xu et al., 2000). Allard et al. (1990) utilizaram PCR no diagnóstico de infecções por adenovírus, em comparação com as técnicas de hemaglutinação em látex e análise de restrição do DNA viral, aplicando-as em amostras fecais e amostras cultivadas em células. Estes autores observaram que a reação de PCR é mais sensível que a hemaglutinação e que a restrição enzimática do DNA, além disso, nesta última metodologia, são necessárias diversas passagens das amostras em cultura para aumentar a quantidade de DNA viral e consequentemente sua sensitividade.

A partir da amplificação de certas regiões do genoma viral, é possível a observação de variações genômicas após análise das sequências nucleotídicas obtidas pela reação de sequenciamento. A partir desta metodologia, é possível também o estabelecimento de relações filogenéticas entre diferentes sorotipos ou até mesmo genotipos, coletados em diferentes partes do mundo e análise da variabilidade genética e evolução dos adenovírus (Kajon et al., 2005; Kidd et al.,1990).

Madisch e colaborados (2005) estabeleceram um critério de classificação dos adenovírus humanos, baseado no sequenciamento nos epitopos de neutralização (hexon) e de hemaglutinação (fibra). Estes pesquisadores observaram que o sequenciamento e análise nucleotídica destes dois genes são suficientes para caracterização taxonômica dos adenovírus humanos, em comparação com os testes de neutralização e de inibição da hemaglutinação. 


\subsection{Evolução viral}

Os adenovírus, isolados de espécies de peixes a humanos, sofrem durante o tempo, processos evolutivos em função da adaptação ao hospedeiro. Estes processos são evidenciados através de variações que ocorrem em seus ácidos nucleicos. Os adenovírus coevoluiram com seus hospedeiros e são classificados em quatro gêneros e cada gênero possui diferentes espécies e sorotipos.

As mutações que ocorrem no genoma viral são induzidas pela pressão seletiva do hospedeiro e pelo ambiente e contribuem para sua evolução, produzindo variabilidade fenotípicas. Essas alterações gênicas são expressas como: reconhecimento de diferentes receptores, tropismo celular, resistência às drogas, alterações na virulência, escape da resposta imunológica do hospedeiro entre outras. O estudo da evolução dos adenovírus permite a compreensão das interações entre proteínas virais e processos celulares do hospedeiro, bem como a utilização destes vírus como vetores virais em terapias gênicas (Davison et al., 2003).

Os tipos genômicos são variantes virais selecionados pela natureza que, mantém sua variabilidade genética após sucessivas passagens em cultivo. (Adrian et al., 1986). Um mesmo tipo genômico pode estar disseminado, sendo isolado em diferentes continentes, enquanto outros são restritos a algumas regiões geográficas (Moura et al., 2007).

Mais de 200 tipos genômicos (genótipos) de adenovírus já foram descritos, sendo as maiores variabilidades observadas nas espécies B, C e D. Para alguns sorotipos já foram descritos mais de 40 genótipos. A genotipagem é obtida através da restrição do DNA genômico com várias endonucleases e posterior comparação dos perfis de restrição com protótipos e variantes virais (Adrian et al., 1989, 1990; Harsi et al., 1995; Kajon et al., 1990, 1993, 1994, 1996; Li et al., 1996; Li e Wadell, 1986, 1988).

O primeiro trabalho abordando as relações filogenéticas entre entre os sorotipos de adenovírus foi realizado por Bailey e Mautner, no ano de 1994. Neste trabalho, foram analisadas sequências depositadas em bancos de dados, de dois ou três representantes de cada espécie de adenovírus humanos. Foram analisadas diferentes regiões do genoma viral e distâncias filogenéticas entre os vírus estudados foram estabelecidas. Kidd et al. (1995), por meio da análise das sequências do gene VA-RNA, estabeleceram relações filogenéticas entre as espécies de adenovírus causadores de doenças em humanos e alguns macacos. Este estudo foi realizado com os protótipos virais de cada espécie do gênero Mastadenovirus. Recentemente importantes trabalhos têm sido realizados sobre a evolução da família 
Adenoviridae, através de comparações entre seqüências genômicas específicas dos diferentes gêneros e espécies (Bënko e Harrach, 2003; Davison, 2003), utilizando também vírus protótipos de cada espécie e seus sorotipos.

$\mathrm{Na}$ análise evolutiva da família Adenoviridae, observou-se que novos genes surgiram, ao longo da adaptação ao hospedeiro, sendo estes exclusivos de cada gênero ou espécie. Dentre estes podemos citar genes nas regiões E1A, E3 e os genes codificadores das proteínas V e IX (somente são observados no gênero Mastadenovirus). Os genes VA-RNA só são observados em adenovírus humanos e de alguns macacos e sua duplicação aparece apenas nos sorotipos das espécies B e C (Benko e Harrach, 2003). Rearranjos, inserções, deleções e o aparecimento de novos genes em um organismo são indicadores do nível de plasticidade genômica, importante para a adaptação do parasita ao hospedeiro (Matioli, 2001).

As recombinações ocorrem entre sorotipos próximos de uma mesma espécie. Exemplos de recombinação entre os HAdVs são: a proteína da fibra do HAdV-7 da espécie B e as fibras dos HAdV-40 e HAdV-41 da espécie F. A proteína da fibra do genótipo HAdV-7h possui maior similaridade com os representantes do sorotipo 3 do que com os do sorotipo 7 . Os adenovírus da espécie F possuem dois tipos de fibras distintas (longa e curta); a fibra longa tem grande semelhança com a fibra dos adenovírus da espécie $\mathrm{C}$ e a fibra curta assemelha-se a fibra de espécies de adenovírus que infectam símios (Kidd et al., 1993).

Captura de genes ocorre quando o vírus adquire seqüências do genoma do hospedeiro ou de outros vírus com os quais estão em coinfecção. Os genes candidatos a terem surgido a partir desse tipo de mutação são os da DNA polimerase, da proteína IX, da dUTPase (Benko e Harrach, 2003).

Para os estudos filogenéticos dos adenovírus humanos são normalmente utilizados vírus protótipos de cada espécie e sorotipo. Estes protótipo foram os primeiros adenovírus isolados, sendo, a grande maioria, nos anos 50, podendo portanto, não corresponder totalmente aos vírus que circulam nos dias atuais. Surge a necessidade de um trabalho científico que busque a observação das mutações do genoma dos HAdV, representativas ou não de sua evolução, por meio da análise filogenética dos vírus isolados naturalmente, ou seja, os vírus que estão provocando infecções durante um certo período de tempo e em certa região.

Neste trabalho, sequências do DNA dos adenovírus isolados de amostras de secreções nasais, colhidas durante um período de onze anos (de 1995 a 2006) foram analisadas por meio de reações de sequenciamento nucleotídico. As regiões do genoma viral, escolhidas para este estudo (hexon, fibra, E3, VA-RNA) equivalem a aproximadamente $10 \%$ de todo genoma e 
são representativas dos processos envolvidos na infecção do hospedeiro e eficácia da atividade viral. Este trabalho é inédito, de relevância para a saúde pública e vai possibilitar futuros estudos sobre a variabilidade genética, patogenia e distribuição dos adenovírus humanos. 


\section{OBJETIVOS}

- Determinar a freqüência de adenovírus humanos das espécies B e C, associados às Infecções Respiratórias Agudas (IRA), em crianças atendidas pelo Hospital Universitário da USP, São Paulo, SP, nos anos de 1995 a 2006.

- Determinar o sorotipo/genótipo dos adenovírus humanos das espécies B e C detectados na amostragem estudada.

- Analisar a distribuição sazonal e etária dos adenovírus detectados.

- Estudar a variabilidade genética dos adenovírus da espécie B detectados na amostragem, através do sequenciamento dos genes hexon, fibra e VA-RNA, assim como da região E3 (proteínas $12.5 \mathrm{~K}, 16.1 \mathrm{~K}, 19 \mathrm{~K}$ e 7.7 K.) 


\section{CONCLUSÕES}

- Adenovírus humanos foram detectados em 677/3087 (22\%) amostras de secreção nasal analisadas.

- A prevalência de infecções respiratórias agudas por adenovírus, em crianças atendidas no Hospital Universitário da USP, apresentou variação nos anos estudados sendo a mínima de 11\% em 2002 e a máxima de 44\% em 2001.

- Os adenovírus da espécie B, sorotipos 3, 7 e 21 foram os mais freqüentes (69\% do total de adenovírus detectados), seguidos da espécies C, sorotipos 1, 2, 5 e 6 (23\%). Adenovírus da espécie E foram raramente detectados (0,74\%). Em 4,5\% das amostras foram observadas infecções mistas.

- Dentre os adenovírus da espécie C, o sorotipo 1 foi o mais frequente, entre 1995 e 1998. O sorotipo 2 foi o mais prevalente em 1999, e entre os anos de 2003 e 2005. Os sorotipos 5 e 6 foram raramente detectados.

- Dentre os adenovírus da espécie B, o sorotipo 7 foi o mais prevalente entre 1995 e 2002, sendo substituído pelo sorotipo 3 que surge com baixa freqüência nos primeiros anos, aumenta a partir de 1999 e passa a ser o mais prevalente a partir de 2003. O adenovírus sorotipo 21 apareceu apenas em algumas amostras de 2006.

- Crianças menores de um ano de idade foram as mais afetadas por infecções com adenovírus, sendo 69\% em menores de 6 meses e 16\% em crianças de 7 a 12 meses.

- Quatro genótipos de adenovírus da espécie B foram detectados: 7p, 7h, 3p e 3a. Estes apresentaram uma alternância na prevalência ao longo dos anos estudados. Entre 1995 e 1999 tipo mais prevalente foi o 7h, sucedido pelo 7p em 2000 e pelo 3a em 2001. A partir de 2003 surge com maior prevalência o tipo 3p.

- Os genótipos detectados apresentaram grande similaridade nucleotídica com os protótipos do sorotipo ou de variantes, cujas sequiências encontram-se depositadas no 
GenBank. Pequenas mutações pontuais ou deleções foram observadas em algumas das amostras seqüenciadas.

- $\quad$ Não foi observada uma variabilidade temporal dos genótipos encontrados. Muitos deles apresentaram alta similaridade com os protótipos isolados e descritos em 1960.

- $\quad$ A maior variabilidade foi observada na proteína 7.7K da região E3.

- Recombinação foi observada entre os tipos 7h e 3a, mas esta é uma característica conhecida do genótipo $7 \mathrm{~h}$.

- Outros eventos de recombinação foram observados, mas estes merecem uma análise mais detalhada das seqüências obtidas. 


\section{REFERÊNCIAS BIBLIOGRÁFICAS}

Adenovirus Taxonomy. Available from: http://www.vmri.hu/ harrach/ [2007 Ago 20].

Adhikary, AK, Banik U, Suzuki E, Inada T, Okabe N. Heterogeneity of the fiber sequence in subgenus C adenoviruses. J Clin Pathol. 2004; 57:612-617.

Adrian T, Wadell G, Hierholzer JC, Wigand R. DNA restriction analysis of adenovirus prototypes 1 to 41. Arch Virol. 1986; 91:277-90.

Adrian T, Best B, Hierholzer JC, Wigand RJ. Molecular epidemiology and restriction site mapping of adenovirus type 3 genome types. Clin Microbiol. 1989;27:1329-34.

Adrian T, Sassinek J, Wigand R. Genome type analysis of 480 isolates of adenovirus types 1, 2, and 5. Arch Virol. 1990;112(3-4):235-48.

Allard A, Girones R, Juto P, Wadell GJ. Polymerase chain reaction for detection of adenoviruses in stool samples. Clin Microbiol. 1990; 28(12):2659-67.

Angeletti PC, Engler JA. Adenovirus preterminal protein binds to the CAD enzyme at active sites of viral DNA replication on the nuclear matrix. J Virol. 1998;72(4):2896-904.

Ariga T, Shimada Y, Ohgami K, Tagawa Y, Ishiko H, Aoki K, Ohno SJ. New genome type of adenovirus serotype 4 caused nosocomial infections associated with epidemic conjunctivitis in Japan. Clin Microbiol. 2004;42(8):3644-8.

Bailey AS, Richmond SJ. Genetic heterogeneity of recent isolates of adenovirus types 3, 4, and 7. J Clin Microbiol. 1986;24(1):30-5.

Bailey A, Mautner V. Phylogenetic relationships among adenovirus serotypes. Virology. 1994;205(2):438-52.

Banco de Dados do Sistema Único de Saúde. Disponível em: http://www.datasus.gov.br [2009 Marc 23].

Barenfanger J, Drake C, Leon N, Mueller T, Troutt T. Clinical and financial benefits of rapid detection of respiratory viruses: an outcome study. J Clin Microbial. 2000;38(8):2824-8. 
Basic Local Alignment Search Tool (Blast). Available from: www.ncbi.nlm.nih.gov/ Education/BLASTinfo /information3.html [2008].

Bënko M, Harrach B. Molecular evolution of adenoviruses. Curr Top Microbiol Immunol. 3003;272:3-35.

Bergelson JM, Cunningham JA, Droguett G, Kurt-Jones EA, Krithivas A, Hong JS, Horwitz MS, Crowell RL, Finberg RW. Isolation of a common receptor for Coxsackie B viruses and adenoviruses 2 and 5. Science. 1997;28;275(5304):1320-3.

Binger MH, Flint SJ. Acumulation of early and intermediate mRNA species during subgroup C adenovirus productive infections. Virology. 1984;136(2)387-403.

Biological sequence alignment editor (BioEdit). Available from: http://www.mbio.ncsu.edu/ BioEdit/bioedit.html [2008 e 2009].

Botosso VF, Zanotto PM, Ueda M, Arruda E, Gilio AE, Vieira SE, Stewien KE, Peret TC, Jamal LF, Pardini MI, Pinho JR, Massad E, Sant'anna OA, Holmes EC, Durigon EL; VGDN Consortium. Positive selection results in frequent reversible amino acid replacements in the $G$ protein gene of human respiratory syncytial virus. PLoS Pathog. 2009;5(1):e1000254.

Bridge E, Ketner G. Redundant control of adenovirus late gene expression by early region 4. J Virol. 1989;63(2):631-8.

Burgert, HG, Blusch JH. Immunomodulatory functions encoded by a E3 transcription unit os adenoviruses. Virus Genes. 2000;21:13-25.

Canducci F, Debiaggi M, Sampaolo M, Marinozzi MC, Berrè S, Terulla C, Gargantini G, Cambieri P, Romero E, Clementi M. Two-year prospective study of single infections and coinfections by respiratory syncytial virus and viruses identified recently in infants with acute respiratory disease. J Med Virol. 2008;80(4):716-23.

Cao J, Arulanandam R, Vultur A, Anagnostopoulou A, Raptis L. Adenovirus E1A requires cRas for full neoplastic transformation or suppression of differentiation of murine preadipocytes. Mol Carcinog. 2007;46:284-302.

Casas I, Avellon A, Mosquera M, Jabado O, Echevarria JE, Campos RH, Rewers M, PerezBreña P, Lipkin WI, Palacios G. Molecular identification of adenoviruses in clinical samples by analyzing a partial hexon genomic region. J Clin Microbiol. 2005;43(12):6176-82. 
Chatterjee PK, Vayda ME, Flint SJ. Adenoviral protein VII packages intracellular viral DNA throughout the early phase of infection. EMBO J. 1986;5:1633-44.

Chiou SK, Tseng CC, Rao L, White E. Functional complementation of the adenovirus E1B 19-kilodalton protein with Bcl-2 in the inhibition of apoptosis in infected cells. J Virol. 1994;68:6553-66.

Chroboczek J, Bieber F, Jacrot B. The sequence of the genome of adenovirus type 5 and its comparison with the genome of adenovirus type 2. Virology. 1992;186:280-5.

Chroboczek J, Ruigrok RW, Cusack S. Adenovirus fiber. Curr Top Microbiol Immunol. 1995; 199:163-200.

Coiras MT, Aguilar ML, Casas I, Pérez-Breña P. Simultaneous detection of fourteen respiratory viruses in clinical specimens by two multiplex reverse transcription Nested-PCR Assays J Med Virol. 2004;72:484-495.

Costa LF, Yokosawa J, Mantese OC, Oliveira TF, Silveira HL, Nepomuceno LL, Moreira LS, Dyonisio G, Rossi LM, Oliveira RC, Ribeiro LZ, Queiróz DA. Respiratory viruses in children younger than five years old with acute respiratory disease from 2001 to 2004 in Uberlândia, MG, Brazil. Mem Inst Oswaldo Cruz. 2006;101(3):301-6.

Crawford-Miksza L, Schnurr DP. Analysis of 15 adenovirus hexon proteins reveals the location and structure of seven hypervariable regions containing serotype-specific residues. $\mathbf{J}$

Virol. 1996;70:1836-1844.

Dales S, Chardonnet Y. Early events in the interaction of adenoviruses with HeLa cells IV Association with microtubules and the nuclear pore complex during vectorial movement of the inoculum. Virology. 1973;56(2):465-83.

Davison AJ, Benko M, Harrach B. Genetic content and evolution of adenoviruses. J Gen Virol. 2003;84:2895-908.

de Arruda E, Hayden FG, McAuliffe JF, de Sousa MA, Mota SB, McAuliffe MI, Geist FC, Carvalho EP, Fernandes MC, Guerrant RL. Acute respiratory viral infections in ambulatory children of urban northeast Brazil. J Infect Dis. 1991;164(2):252-8.

de Jong JC, Wigand R, Wadell G, Keller D, Muzerie CJ, Wermenbol AG, Schaap GJ. Adenovirus 37: identification and characterization of a medically important new adenovirus type of subgroup D. J Med Virol. 1981;7(2):105-18. 
de Jong JC, Wermenbol AG, Verweij-Uijterwaal MW, Slaterus KW, Wertheim-Van Dillen P, Van Doornum GJ, Khoo SH, Hierholzer JC. Adenoviruses from human immunodeficiency virus-infected individuals, including two strains that represent new candidate serotypes Ad50 and Ad51 of species B1 and D, respectively. J Clin Microbiol. 1999;37(12):3940-5.

Dragulev BP, Sira S, Abouhaidar MG, Campbell JB. Sequence analysis of putative E3 and fiber genomic regions of two strains of canine adenovirus type 1. Virology. 1991;183(1):298305 .

Ebner K, Pinsker W, Lion T. Comparative sequence analysis of the hexon gene in the entire spectrum of human adenovirus serotypes: phylogenetic, taxonomic, and clinical implications. J Virol. 2005;79(20):12635-42.

Ebner K, Rauch M, Preuner S, Lion T. Typing of human adenoviruses in specimens from immunosuppressed patients by PCR-fragment length analysis and real-time quantitative PCR. J Clin Microbiol. 2006;44(8):2808-15.

Echavarria M, Maldonado D, Elbert G, Videla C, Rappaport R, Carballal G. Use of PCR to demonstrate presence of adenovirus species B, C, or F as well as coinfection with two adenovirus species in children with flu-like symptoms. J Clin Microbiol. 2006; Feb;44(2):625-7.

Enders JF, Bell JA, Dingle JH, Francis T Jr, Hilleman MR, Huebner RJ, Payne AM Adenoviruses: group name proposed for new respiratory-tract viruses. Science. 1956;124:11920 .

Erdman DD, Xu W, Gerber SI, Gray GC, Schnurr D, Kajon AE, Anderson LJ. Molecular epidemiology of adenovirus type 7 in the United States, 1966-2000. Emerg Infect Dis. 2002;8(3):269-77.

Fackeldey, ER, Aumeier S, Boroviczény OG. Disseminated adenovirus infection in two premature infants. Infection. 2000; 28:237-239.

Felsenstein J. Evolutionary trees from DNA sequences: a maximum likelihood approach. J Mol Evol. 1981;17(6):368-76.

Fessler SP, Delgado-Lopez F, Horwitz MS. Mechanisms of E3 modulation of immune and inflammatory responses. Curr Top Microbiol Immunol. 2004;273:113-35. 
Field J, Gronostajski RM, Hurwitz J. Properties of the adenovirus DNA polymerase. J Biol Chem. 1984;259:9487-95.

Fredman JN, Engler JA. Adenovirus precursor to terminal protein interacts with the nuclear matrix in vivo and in vitro. J Virol. 1993;67:3384-95.

Frisch SM, Mymryk JS. Adenovirus-5 E1A: paradox and paradigm. Nat Rev Mol Cell Biol. 2002;3(6):441-52.

Gahéry-Ségard H, Farace F, Godfrin D, Gaston J, Lengagne R, Tursz T, Boulanger P, Guillet JG. Immune response to recombinant capsid proteins of adenovirus in humans: antifiber and anti-penton base antibodies have a synergistic effect on neutralizing activity. J Virol. 1998;72(3):2388-97.

Ginsberg HS, Lundholm-Beauchamp U, Horswood RL, Pernis B, Wold WSM, Chanock RM, Prince GA. Role of early region 3 (E3) in pathogenesis of adenovirus disease. Proc Natl Acad Sci USA. 1989;86:3823-3827.

Ghosh-Choudhury G, Haj-Ahmad Y, Graham FL. Protein IX, a minor component of the human adenovirus capsid, is essential for the packaging of full length genomes. EMBO J. 1987 Jun;6(6):1733-9.

Gomes SA, Candeias JA, Monteiro SP, Pereira HG, Niel C. New genome types of adenovirus types 1, 3, and 5 isolated from stools of children in Brazil. J Clin Microbiol. 1989;27(5):10226.

Gonçalves MA, de Vries AA. Adenovirus: from foe to friend. Rev Med Virol. 2006;16:16786.

Gooding LR, Aquino L, Duerksen-Hughes PJ, Day D, Horton TM, Yei SP, Wold WS. The E1B 19,000-molecular-weight protein of group C adenoviruses prevents tumor necrosis factor cytolysis of human cells but not of mouse cells. J Virol. 1991;65:3083-94.

Gray GC, Goswami PR, Malasig MD, Hawksworth AW, Trump DH, Ryan MA, Schnurr DP. Adult adenovirus infections: loss of orphaned vaccines precipitates military respiratory disease epidemics. For the Adenovirus Surveillance Group. Clin Infect Dis. 2000;31(3):66370 . 
Gray GC, McCarthy T, Lebeck MG, Schnurr DP, Russell KL, Kajon AE, Landry ML, Leland DS, Storch GA, Ginocchio CC, Robinson CC, Demmler GJ, Saubolle MA, Kehl SC, Selvarangan R, Miller MB, Chappell JD, Zerr DM, Kiska DL, Halstead DC, Capuano AW, Setterquist SF, Chorazy ML, Dawson JD, Erdman DD. Genotype prevalence and risk factors for severe clinical adenovirus infection, United States 2004-2006. Clin Infect Dis. 2007 Nov 1;45(9):1120-31.

Greber UF, Webster P, Weber J, Helenius A. The role of the adenovirus protease on virus entry into cells. EMBO J. 1996;15:1766-77.

Greber UF, Suomalainen M, Stidwill RP, Boucke K, Ebersold MW, Helenius A. The role of the nuclear pore complex in adenovirus DNA entry. EMBO J. 1997;16:5998-6007.

Greber UF. Virus assembly and disassembly: the adenovirus cysteine protease as a trigger factor. Rev Med Virol. 1998;8:213-222.

Guo DF, Shinagawa M, Aoki K, Sawada H, Itakura S, Sato G. Genome typing of adenovirus strains isolated from conjunctivitis in Japan, Australia, and the Philippines. Microbiol Immunol. 1988;32(11):1107-18.

Harada JN, Shevchenko A, Shevchenko A, Pallas DC, Berk AJ. Analysis of the adenovirus E1B-55K-anchored proteome reveals its link to ubiquitination machinery. J Virol. 2002;76:9194-206.

Hársi CM, Rolim DP, Gomes SA, Gilio AE, Stewien KE, Baldacci ER, Candeias JA. Adenovírus genome types isolated from stools of children with gastroenteritis in Sao Paulo, Brazil. J Med Virol. 1995;26:1783-6.

Hashido M, Mukouyama A, Sakae K, Tsuzuki H, Yamashita T, Inada T, Inouye S. Molecular and serological characterization of adenovirus genome type $7 \mathrm{~h}$ isolated in Japan. Epidemiol Infect. 1999 Apr;122(2):281-6.

Hawkins LK, Wold WS. A 12,500 MW protein is coded by region E3 of adenovirus. Virology. 1992;188(2):486-94.

Hawkins LK, Wold WSM. The E3-20.5K membrane protein of subgroup B human adenoviruses contains o-linked and complex n-linked oligosaccharides. Virology. 1995;210:335-344. 
Hawkins LK, Wilson-Rawls J, Wold WS. Region E3 of subgroup B Human Adenoviruses encodes a 16-kilodalton membrane protein that may be a distant analog of E3-6.7K protein of subgroup C adenoviruses. J Virol. 1995; 69(7):4292-98.

Hay RT, Freeman A, Leith I, Monaghan A, Webster A. Molecular interactions during adenovirus DNA replication. Curr Top Microbiol Immunol. 1995;199:31-48.

Hierholzer JC. Adenoviruses in the immunocompromised host. Clin Microbiol Rev. 1992;5(3):262-74

Hilleman MR, Werner JH. Recovery of new agent from patients with acute respiratory illness. Proc Soc Exp Biol Med. 1954;85(1) 183-8.

Hogg JC. The adenovirus and bronchopulmonary dysplasia: an association that could be causal or coincidental. Pediatr Res. 2000;47(2):175-6.

Hong SS, Habib NA, Franqueville L, Jensen S, Boulanger PA. Identification of adenovirus (ad) penton base neutralizing epitopes by use of sera from patients who had received conditionally replicative ad (add11520) for treatment of liver tumors. J Virol. 2003;77(19):10366-75.

Horwitz, M. Adenoviruses. In: Fields B, Knipe D, Howley PM, editors. Fields Virology. Philadelphia: Lippincott-Raven Publishers; 1996. Chapter 67; p2149-2171. 1996.

Horwitz MS. Adenovirus immunoregulatory genes and their cellular targets. Virology. 2001;279:1-8.

Horwitz MS. Function of adenovirus E3 proteins and their interactions with immunoregulatory cell proteins. J Gen Med. 2004;6:172-183.

Huang MM, Hearing P. Adenovirus early region 4 encodes two gene products with redundant effects in lytic infection. J Virol. 1989;63(6):2605-15

Huebner RJ, Casey MJ, Chanock RM, Schell K. Tumors induced in hamsters by a strain of adenovirus type 3: sharing of tumor antigens and "neoantigens" with those produced by adenovirus type 7 tumors. Proc Natl Acad Sci U S A. 1965;54(2):381-8. 
Ikeda JE, Enomoto T, Hurwitz J. Replication of adenovirus DNA-protein complex with purified proteins. Proc Natl Acad Sci U S A. 1981;78(2):884-8.

International Committee on Taxonomy of Viruses. Adenoviruses. Available from: http://www.ncbi.nlm.nih.gov/ICTVdb/WIntkey/Images/em_adeno.gif [2007 dez 12].

Ison MG. Adenovirus infections in transplant recipients. Clin Infect Dis. 2006;43(3):331-9.

Jones MS 2nd, Harrach B, Ganac RD, Gozum MM, Dela Cruz WP, Riedel B, Pan C, Delwart EL, Schnurr DP. New adenovirus species found in a patient presenting with gastroenteritis. J Virol. 2007;81:5978-84.

Kajon AE, Murtagh P, Garcia Franco S, Freire MC, Weissenbacher MC, Zorzópulos J. A new genome type of adenovirus 3 associated with severe lower acute respiratory infection in children. J Med Virol. 1990;30(1):73-6.

Kajon A, Wadell G. Characterization of adenovirus genotype 7h: analysis of its relationship to other member of serotype 7. Intervirology. 1992;33:86-90.

Kajon AE, Suárez MV, Avendaño LF, Hortal M, Wadell G. Genome type analysis of South American adenoviruses of subgenus $\mathrm{C}$ collected over a 7-year period. Arch Virol. 1993;132(1-2):29-35.

Kajon AE, Larranaga C, Suarez M, Wadell G, Avedano LF. Genome type analysis of chilean adenovírus strains isolated in chindren's hospital between 1998 and 1990. J Med Virol. 1994;42:16-21.

Kajon AE, Mistchenko AS, Videla C, Hortal M, Wadell G, Avedano LF. Molecular epidemiology of adenovirus acute lower respiratory infections of children in the south cone of South America (1991-1994). J Med Virol. 1996;48:151-156.

Kajon AE, Wadell G. Sequence analysis of the E3 region and fiber gene of human adenovirus genome type 7h. Virology. 1996;215(2):190-6.

Kajon AE, Xu W, Erdman DD. Sequence polymorphism in the E3 7.7 ORF of subspecies B1 human adenoviruses. Virus Res. 2005;107:11-19. 
Kajon AE, Erdman DD. Assessment of genetic variability among subspecies b1 human adenoviruses for molecular epidemiology studies. Methods Mol Med. 2007;131:335-55.

Kaneko H, Maruko I, Iida T, Ohguchi T, Aoki K, Ohno S, Suzutani T. The possibility of human adenovirus detection from the conjunctiva in asymptomatic cases during nosocomial infection. Cornea. 2008;27(5):527-30.

Katze MG, DeCorato D, Safer B, Galabru J, Hovanessian AG. Adenovirus VAI RNA complexes with the $68000 \mathrm{Mr}$ protein kinase to regulate its autophosphorylation and activity. EMBO J. 1987;6(3):689-97.

Kidd AH, Erasmus MJ, Tiemessen CT. Fiber sequence heterogeneity in subgroup F adenoviruses.Virology. 1990;179:139-50.

Kidd AH, Chroboczek J, Cusack S, Ruigrok RW. Adenovirus type 40 virions contain two distinct fibers. Virology. 1993;192:73-84.

Kidd AH, Garwicz D, Oberg M. Human and simian adenoviruses: phylogenetic inferences from analysis of VA RNA genes. Virology. 1995;207:32-45.

Kim YJ, Hong JY, Lee HJ, Shin SH, Kim YK, Inada T, Hashido M, Piedra PA. Genome type analysis of adenovirus types 3 and 7 isolated during successive outbreaks of lower respiratory tract infection in children. J Clin Microbiol. 2003;41:4594-4599.

King AJ, Teertstra WR, van der Vliet PC. Dissociation of the protein primer and DNA polymerase after initiation of adenovirus DNA replication. J Biol Chem. 1997;272:24617-23.

Kitajewski J, Schneider R, Safer B, Munemitsu S M, Samuel CE, Thimmappaya B, Shenk T. Adenovirus VA-RNA antagonizes the antiviral action of interferon by preventing activation of the interferon-induced eIF-2 alpha kinase. Cell. 1986; 45:95-200.

Kleinberger T, Shenk T. Adenovirus E4orf4 protein binds to protein phosphatase 2A, and the complex down regulates E1A-enhanced junB transcription. J Virol. 1993;67(12):7556-60.

Kleinberger T. Induction of apoptosis by adenovirus E4orf4 protein. Apoptosis. 2000;5(3):211-5. 
Krajcsi P, Dimitrov T, Hermiston TW, Tollefson AE, Ranheim TS, Vande Pol SB, Stephenson AH, Wold WS. The adenovirus E3-14.7K protein and the E3-10.4K/14.5K complex of proteins, which independently inhibit tumor necrosis factor (TNF)-induced apoptosis, also independently inhibit TNF-induced release of arachidonic acid. J Virol. 1996;70(8):4904-13.

Laham FR, Jewell AM, Schoonover SL, Demmler GJ, Piedra PA. The search for adenovirus 14 in children in Houston, Texas. Pediatr Infect Dis J. 2008;27(7):653-4.

Leen AM, Sili U, Vanin EF, Jewell AM, Xie W, Vignali D, Piedra PA, Brenner MK, Rooney CM. Conserved CTL epitopes on the adenovirus hexon protein expand subgroup crossreactive and subgroup-specific CD8+ T cells. Blood. 2004 Oct 15;104(8):2432-40.

Leopold PL, Kreitzer G, Miyazawa N, Rempel S, Pfister KK, Rodriguez-Boulan E, Crystal RG. Dynein- and microtubule-mediated translocation of adenovirus serotype 5 occurs after endosomal lysis. Hum Gene Ther. 2000;11:151-65.

Leppard KN, Everett RD. The adenovirus type $5 \mathrm{E} 1 \mathrm{~b} 55 \mathrm{~K}$ and E4 Orf3 proteins associate in infected cells and affect ND10 components. J Gen Virol. 1999;80:997-1008.

Lewis PF, Schmidt MA, Lu X, Erdman DD, Campbell M, Thomas A, Cieslak PR, Grenz LD, Tsaknardis L, Gleaves C, Kendall B, Gilbert D. A community-based outbreak of severe respiratory illness caused by human adenovirus serotype 14. J Infect Dis. 2009;199(10):142734.

Li QG, Wadell G. Analysis of 15 different genome types of adenovirus type 7 isolated on five continents. J Virol. 1986;60(1):331-5.

Li QG, Wadell G. Comparison of 17 genome types of adenovirus type 3 identified among strains recovered from six continents. J Clin Microbiol. 1988;26(5):1009-15.

Li QG, Zheng QJ, Liu YH, Wadell G. Molecular epidemiology of adenovirus types 3 and 7 isolated from children with pneumonia in Beijing. J Med Virol. 1996;49(3):170-7.

Li Q, Wadell G. Genetic variability of hexon loops 1 and 2 between seven genome types of adenovirus serotype 7. Arch Virol. 1999;144(9):1739-49.

Lichtenstein DL, Toth K, Doronin K, Tollefson AE, Wold WS. Functions and mechanisms of action of the adenovirus E3 proteins. Int Rev Immunol. 2004;23:75-111. 
Liu HT, Baserga R, Mercer WE. Adenovirus type 2 activates cell cycle-dependent genes that are a subset of those activated by serum. Mol Cell Biol. 1985;5(11):2936-42.

Liu GQ, Babiss LE, Volkert FC, Young CS, Ginsberg HS. A thermolabile mutant of adenovirus 5 resulting from a substitution mutation in the protein VIII gene. J Virol. 1985;53(3):920-5.

Liu HT, Naismith JH, Hay RT. Adenovirus DNA replication. Curr Top Microbiol Immunol. 2003;272:131-64.

Louis N, Fender P, Barge A, Kitts P, Chroboczek J. Cell-binding domain of adenovirus serotype 2 fiber. J Virol. 1994;68:4104-6.

Lu X, Erdman DD,. Molecular typing of human adenoviruses by PCR and sequencing of a partial region of the hexon gene. Arch Virol. 2006;151:1587-1602.

Ma Y, Mathews MB. Structure, function and evolution of adenovírus associated - RNA: a phylogenetic approach. J Virol. 1996;70:5083-99.

Madisch I, Harste G, Pommer H, Heim A. Phylogenetic analysis of the main neutralization and hemagglutination determinants of all human adenovirus prototypes as a basis for molecular classification and taxonomy. J Virol. 2005;79(24):15265-76.

Mannervik M, Fan S, Ström AC, Helin K, Akusjärvi G. Adenovirus E4 open reading frame 4induced dephosphorylation inhibits E1A activation of the E2 promoter and E2F-1-mediated transactivation independently of the retinoblastoma tumor suppressor protein. Virology. $1999 ; 256(2): 313-21$.

Mathias P, Wickham T, Moore M, Nemerow G. Multiple adenovirus serotypes use alpha v integrins for infection. J Virol. 1994;68:6811-4.

Matioli SR. Biologia Molecular e Evolução. São Paulo: Editora Holos; 2001.

Matthews DA, Russell WC. Adenovirus protein-protein interactions: molecular parameters governing the binding of protein VI to hexon and the activation of the adenovirus $23 \mathrm{~K}$ protease. J Gen Virol. 1995;76:1959-69.

Matthews DA, Russell WC. Adenovirus core protein V interacts with p32--a protein which is associated with both the mitochondria and the nucleus. J Gen Virol. 1998;79:1677-85. 
Medina-Kauwe LK. Endocytosis of adenovirus and adenovirus capsid proteins. Adv Drug Deliv Rev. 2003;55:1485-96.

Mei YF, Lindman K, Wadell G. Human adenoviruses of subgenera B, C, and E with various tropisms differ in both binding to and replication in the epithelial A549 and 293 cells. Virology. 2002;295:30-43.

Mei YF, Skog J, Lindman K, Wadell G. Comparative analysis of the genome organization of human adenovirus 11, a member of the human adenovirus species $\mathrm{B}$, and the commonly used human adenovirus 5 vector, a member of species C. J Gen Virol. 2003;84:2061-71.

Metzgar D, Osuna M, Yingst S, Rakha M, Earhart K, Elyan D, Esmat H, Saad MD, Kajon AE, Wu J, Gray GC, Ryan MA, Russell KL. PCR analysis of Egyptian respiratory adenovirus isolates, including identification of species, serotypes and coinfections. J Clin Microbiol. 2005;43:5743-5752.

Metzgar D, Osuna M, Kajon AE, Hawksworth AW, Irvine MI, Russell KL. Abrupt emergence of diverse species B adenoviruses at US military recruit training centers. J Infect Dis. 2007; 196:1465-1473.

Mims C, Ployfair J, Roitt I, Wakelin D, Williams R. Microbiologia Médica.São Paulo: Ed Manole; 1999.

Minnich L, Ray CG. Comparison of direct immunofluorescent staining of clinical specimens for respiratory vírus antigen with conventional isolation techniques. J Clin Microbiol. 1980;12:391-394.

Miura-Ochiai R, Shimada Y, Konno T, Yamazaki S, Aoki K, Ohno S, Suzuki E, Ishiko H. Quantitative detection and rapid identification of human adenoviruses J Clin Microbiol. 2007 Mar;45(3):958-67.

Mizuta K, Matsuzaki Y, Hongo S, Ohmi A, Okamoto M, Nishimura H, Itagaki T, Katsushima N, Oshitani H, Suzuki A, Furuse Y, Noda M, Kimura H, Ahiko T. Stability of the seven hexon hypervariable region sequences of adenovirus types 1-6 isolated in Yamagata, Japan between 1988 and 2007. Virus Res. 2009;140(1-2):32-9.

Molinier-Frenkel V, Lengagne R, Gaden F, Hong SS, Choppin J, Gahery-Ségard H, Boulanger P, Guillet JG. Adenovirus hexon protein is a potent adjuvant for activation of a cellular immune response. J Virol. 2002;76(1):127-35 
Moraes MT, Leite JP, Siqueira MM, Portes SA, Krawczuk MM, Nascimento JP. Genomic characterization of adenovirus serotype 7 isolated in Brazil from acute respiratory disease patients during the period from 1980 to 1991. Rev Inst Med Trop Sao Paulo. 1997;39(4):185189.

Moura PO, Roberto AF, Hein N, Baldacci E, Vieira SE, Ejzenberg B, Perrini P, Stewien KE, Durigon EL, Mehnert DU, Harsi CM. Molecular epidemiology of human adenovírus isolated from children hospitalized with acute respiratory infection in Sao Paulo, Brazil. J Med Virol. v.79:174-181, 2007.

Muruve DA. The innate immune response to adenovirus vectors. Hum Gene Ther. 2004;15(12):1157-66.

Nevels M, Dobner T. Determination of the transforming activities of adenovirus oncogenes. Methods Mol Med. 2007;131:187-95.

Ostapchuk P, Hearing P. Regulation of adenovirus packaging. Curr Top Microbiol Immunol. 2003;272:165-85.

Ostapchuk P, Yang J, Auffarth E, Hearing P. Functional interaction of the adenovirus IVa2 protein with adenovirus type 5 packaging sequences. J Virol. 2005;79(5):2831-8.

Palomino MA, Larrañaga C, Avendaño LF. Hospital-acquired adenovirus $7 \mathrm{~h}$ infantile respiratory infection in Chile. Pediatr Infect Dis J. 2000;19(6):527-31.

Persson $\mathrm{H}$, Jörnvall $\mathrm{H}$, Zabielski J. Multiple mRNA species for the precursor to an adenovirus-encoded glycoprotein: identification and structure of the signal sequence. Proc Natl Acad Sci U S A. 1980;77:6349-53.

Pieniazek NJ, Slemenda SB, Pieniazek D, Velarde J Jr, Luftig RB. Human enteric adenovirus type 41 (Tak) contains a second fiber protein gene. Nucleic Acids Res. 1990;18:1901.

Pring-Akerblom P, Trijssenaar FE, Adrian T. Hexon sequence of adenovirus type 7 and comparison with other serotypes of subgenus B. Res Virol. 1995;146(6):383-388.

Randall RE, Goodbourn S. Interferons and viruses: an interplay between induction, signalling, antiviral responses and virus countermeasures. J Gen Virol. 2008;89:1-47. 
Räty R, Kleemola M, Melén K, Stenvik M, Julkunen I. Efficacy of PCR and other diagnostic methods for the detection of respiratory adenoviral infections. J Med Virol. 1999;59(1):66-72.

Rekosh DM, Russell WC, Bellet AJ, Robinson AJ. Identification of a protein linked to the ends of adenovirus DNA. Cell. 1977;11(2):283-95.

Roberts DM, Nanda A, Havenga MJ, Abbink P, Lynch DM, Ewald BA, Liu J, Thorner AR, Swanson PE, Gorgone DA, Lifton MA, Lemckert AA, Holterman L, Chen B, Dilraj A, Carville A, Mansfield KG, Goudsmit J, Barouch DH. Hexon-chimaeric adenovirus serotype 5 vectors circumvent pre-existing anti-vector immunity. Nature. 2006;441:239-43.

Roovers DJ, van der Lee FM, van der Wees J, Sussenbach JS. Analysis of the adenovirus type 5 terminal protein precursor and DNA polymerase by linker insertion mutagenesis. $J$ Virol. 1993;67:265-76.

Rosen I. A hemmaglutination inhibition technique for typing adenoviruses. Am J Hyg. 1960;1:120-128.

Rosete DP, Manjarrez ME, Barrón BL. Adenoviruses C in non-hospitalized Mexican children older than five years of age with acute respiratory infection. Mem Inst Oswaldo Cruz. 2008 Mar;103(2):195-200.

Rowe WP, Huebner RJ, Gilmore LK, Parrot RH, Ward TG.Isolation of a cytopathogenic agent from human adenoids undergoing spontaneous degeneration in tissue culture. Proc Soc Exp Biol Med. 1953;84:570-3.

Russell WC. Update on adenovirus and its vectors. J Gen Virol. 2000;81:2573-604.

Russell WC. Adenoviruses: update on structure and function. J Gen Virol. 2009;90:1-20.

Ryan MA, Gray GC, Smith B, McKeehan JA, Hawksworth AW, Malasig MD. Large epidemic of respiratory illness due to adenovirus types 7 and 3 in healthy young adults. Clin Infect Dis. 2002;34(5):577-82.

Saitou N, Nei M. The neighbor-joining method: a new method for reconstructing phylogenetic trees. Mol Biol Evol. 1987;4(4):406-25.

San Martín C, Burnett RM. Structural studies on adenoviruses. Curr Top Microbiol Immunol. 2003;272:57-94. 
Sanalios, RB. Análise comparativa das técnicas de imunofluorescência indireta, isolamento em cultura celular e reação em cadeia da polimerase, no diagnóstico de infecções respiratórias por adenovírus e vírus respiratório sincicial [dissertação (Mestrado em Microbiologia)]. São Paulo: Instituto de Ciências Biomédicas da Universidade de São Paulo; 2004.

Santamaría C, Urueña A, Videla C, Suarez A, Ganduglia C, Carballal G, Bonvehi P, Echavarría M. Epidemiological study of influenza virus infections in young adult outpatients from Buenos Aires, Argentina. Influenza Other Resp Viruses. 2008;2(4):131-4.

Santos, TG. Caracterização genotípica de adenovírus isolados de crianças com infecção respiratória, atendidas entre 1998 e 2000, na cidade de Ribeirão Preto - SP [dissertação (Mestrado em Microbiologia)]. São Paulo: Instituto de Ciências Biomédicas da Universidade de São Paulo; 2007.

Schaack J, Ho WY, Freimuth P, Shenk T. Adenovirus terminal protein mediates both nuclear matrix association and efficient transcription of adenovirus DNA. Genes Dev. 1990;4(7):1197-208.

Schimidt AC, Couch RB, Galasso GJ, Hayden FG, Mills J, Murphy BR, Chanock RM. Current research on respiratory viral infection: Third International symposium. Antiv Res. 2001;50:157-196.

Segerman A. Adenovirus B: Receptors, Tropism and Hematopoietic cells. [Ph.D Thesis]. Umea: Umea University; 2004.

Seth P. Adenovirus-dependent release of choline from plasma membrane vesicles at an acidic $\mathrm{pH}$ is mediated by the penton base protein. Virology. 1994;68:1204-6.

Shenk TE. Adenoviridae: the viruses and their replication. In: Fields B, Knip D, Howley, PM, editors. Fields Virology. Philadelphia: Lippincott-Raven Publishers; 1996. Chapter 67.

Shiao S, Aoki K, Isobe K, Tsuzuki WL, Itoh N, Toba K, Kobayashi N, Noguchi Y, Ohno S. Genome analysis of adenovirus type 3 isolated in Japan. J Clin Microbiol. 1996;34(2):413-6.

Shimada Y, Ariga T, Tagawa Y, Aoki K, Ohno S, Ishiko H. Molecular diagnosis of human adenoviruses $\mathrm{d}$ and e by a phylogeny-based classification method using a partial hexon sequence. J Clin Microbiol. 2004;42(4):1577-84.

Shinagawa M, Matsuda A, Ishiyama T, Sato G. A rapid and simple method for preparation of adenoviruses DNA from infected cells. Microbiol Immunol. 1983;27:817-822. 
Sinaniotis CA. Viral pneumoniae in children: incidence and aetiology. Pediatric Resp Rev. 2004;5:197-200.

Siqueira-Silva J. Estudo da interação do adenovírus humano, sorotipo 41 (HAdV-41), com células permissívas [dissertação (Doutorado em Microbiologia)]. São Paulo: Instituto de Ciências Biomédicas da Universidade de São Paulo; 2008.

Siqueira-Silva J, Yeda FP, Favier AL, Mezin P, Silva ML, Barrella KM, Mehnert DU, Fender P, Harsi CM. Infection kinetics of human adenovirus serotype 41 (HAdV-41) in 293 cells. Mem Inst Oswal Cruz. In press.

Sistema Estadual de Análises de Dados. Disponível em: http://www.seade.gov.br [2009 Marc 23].

Stallwood Y, Fisher KD, Gallimore PH, Mautner V. Neutralisation of adenovirus infectivity by ascitic fluid from ovarian cancer patients. Gene Ther. 2000;7(8):637-43.

Stewart PL, Fuller SD, Burnett RM.Difference imaging of adenovirus: bridging the resolution gap between X-ray crystallography and electron microscopy. EMBO J. 1993;12:2589-99.

Straube RC, Thompson MA, Van Dyke RB, Wadell G, Connor JD, Wingard D, Spector SA. Adenovirus type 7b in a children's hospital. J Infect Dis. 1983;147(5):814-9.

Sumida SM, Truitt DM, Lemckert AA, Vogels R, Custers JH, Addo MM, Lockman S, Peter T, Peyerl FW, Kishko MG, Jackson SS, Gorgone DA, Lifton MA, Essex M, Walker BD, Goudsmit J, Havenga MJ, Barouch DH. Neutralizing antibodies to adenovirus serotype 5 vaccine vectors are directed primarily against the adenovirus hexon protein. J Immunol. 2005;174(11):7179-85.

Suomalainen M, Nakano MY, Keller S, Boucke K, Stidwill RP, Greber UF. Microtubuledependent plus- and minus end-directed motilities are competing processes for nuclear targeting of adenovirus. J Cell Biol. 1999;144(4):657-72.

Takahashi A, Higashino F, Aoyagi M, Nakayama M, Yanagawa A, Hasegawa H, Hatta M, Ishida S, Nakajima K, Totsuka Y, Shindoh M. Adenovirus E1A negatively regulates E1AF, an ets family of the protein. Biochem Biophys Res Commun. 2007;355:438-43.

Tamanini A, Nicolis E, Bonizzato A, Bezzerri V, Melotti P, Assael BM, Cabrini G. Interaction of adenovirus type 5 fiber with the coxsackievirus and adenovirus receptor activates inflammatory response in human respiratory cells. J Virol. 2006;80(22):11241-54. 
Tamura K, Dudley J, Nei M, Kumar S MEGA4: Molecular Evolutionary Genetics Analysis (MEGA) software version 4.0. Mol Biol Evol. 2007;24:1596-1599.

Tanaka K, Itoh N, Inagawa WS, Uchio E, Takeuchi S, Aoki K, Soriano E, Nishi M, Belfort R Jr, Harsi CM, Wang LT, Durigon EL, Stewien KE, Ohno S. Genetic characterization of adenovirus strains isolated from patients with acute conjunctivitis in the city of São Paulo, Brazil. J Med Virol. 2000;61:143-149.

Tang LF, Wang TL, Tang HF, Chen ZM. Viral pathogens of acute lower respiratory tract infection in China. Indian Pediatr. 2008;45(12):971-5.

Tarassishin L, Szawlowski P, Kidd AH, Russell WC. An epitope on the adenovirus fibre tail is common to all human subgroups. Arch Virol. 2000;145(4):805-11.

Tate JE, Bunning ML, Lott L, Lu X, Su J, Metzgar D, Brosch L, Panozzo CA, Marconi VC, Faix DJ, Prill M, Johnson B, Erdman DD, Fonseca V, Anderson LJ, Widdowson MA. Outbreak of Severe Respiratory Disease Associated with Emergent Human Adenovirus Serotype 14 at a US Air Force Training Facility in 2007. J Infect Dis. 2009;199(10):14191426.

Tiemessen CT, Kidd AH. The subgroup F adenoviruses. J Gen Virol. 1995;76:481-97.

Tollefson AE, Krajcsi P, Pursley MH, Gooding LR, Wold WS. A 14,500 MW protein is coded by region E3 of group C human adenoviruses.Virology. 1990;175:19-29.

Tollefson AE, Ryerse JS, Scaria A, Hermiston TW, Wold WS.The E3-11.6-kDa adenovirus death protein (ADP) is required for efficient cell death: characterization of cells infected with adp mutants. Virology. 1996;220:152-62.

Trentin JJ, Yabe Y, Taylor G. The quest for human cancer viruses. Science. 1962;137:835-41.

Tribouley C, Lutz P, Staub A, Kedinger C. The product of the adenovirus intermediate gene IVa2 is a transcriptional activator of the major late promoter. J Virol. 1994;68:4450-7.

Trotman LC, Mosberger N, Fornerod M, Stidwill RP, Greber UF. Import of adenovirus DNA involves the nuclear pore complex receptor CAN/Nup214 and histone H1. Nat Cell Biol. 2001;3:1092-100. 
van Raaij MJ, Louis N, Chroboczek J, Cusack S. Structure of the human adenovirus serotype 2 fiber head domain at 1.5 A resolution.Virology. 1999a;262(2):333-43.

van Raaij MJ, Mitraki A, Lavigne G, Cusack S. A triple beta-spiral in the adenovirus fibre shaft reveals a new structural motif for a fibrous protein.Nature. 1999b;401(6756):935-8.

Vellinga J, Van der Heijdt S, Hoeben RC. The adenovirus capsid: major progress in minor proteins J Gen Virol. 2005;86:1581-8.

Verrijzer CP, van Oosterhout JA, van Weperen WW, van der Vliet PC. POU proteins bend DNA via the POU-specific domain. EMBO J. 1991;10:3007-14.

Vieira SE, Stewien KE, Queiroz DA, Durigon EL, Török TJ, Anderson LJ, Miyao CR, Hein N, Botosso VF, Pahl MM, Gilio AE, Ejzenberg B, Okay Y. Clinical patterns and seasonal trends in respiratory syncytial virus hospitalizations in São Paulo, Brazil. Rev Inst Med Trop Sao Paulo. 2001;43(3):125-31.

Vieira SE, Gilio AE, Durigon EL, Ejzenberg B. Lower respiratory tract infection caused by respiratory syncytial virus in infants: the role played by specific antibodies. Clinics (Sao Paulo). 2007;62(6):709-16.

Wadell G. Classification of human adenoviruses by SDS-polyacrylamide gel electrophoresis of structural polypeptides. Intervirology. 1979;11(1):47-57.

Wadell G, Varsányi TM, Lord A, Sutton RN. Epidemic outbreaks of adenovirus 7 with special reference to the pathogenicity of adenovirus genome type $7 \mathrm{~b}$. Am J Epidemiol. 1980;112:619-28.

Wadell G, de Jong JC, Wolontis S. Molecular epidemiology of adenoviruses: alternating appearance of two different genome types of adenovirus 7 during epidemic outbreaks in Europe from 1958 to 1980. Infect Immun. 1981;34(2):368-72.

Wadell G. Molecular epidemiology of human adenoviruses. Curr Top Microbiol Immunol. 1984;110:191-220.

Wadell G, Cooney MK, da Costa Linhares A, de Silva L, Kennett ML, Kono R, Gui-Fang R, Lindman K, Nascimento JP, Schoub BD, et al. Molecular epidemiology of adenoviruses: global distribution of adenovirus 7 genome types. J Clin Microbiol. 1985;21(3):403-8. 
Wasseman FE. The inactivation of adenovirus by ultraviolet irradiation and nitrous acid. Virology. 1962;17:335-341.

Webster A, Leith IR, Hay RT. Activation of adenovirus-coded protease and processing of preterminal protein. J Virol. 1994;68:7292-300.

Wiethoff CM, Wodrich H, Gerace L, Nemerow GR. Adenovirus protein VI mediates membrane disruption following capsid disassembly. J Virol. 2005;79(4):1992-2000.

Wigand R, Sehn N, Hierholzer JC, de Jong JC, Adrian T. Immunological and biochemical characterization of human adenoviruses from subgenus B. I. Antigenic relationships. Arch Virol. 1985;84(1-2):63-78.

Wigand R, Adrian T. Classification and epidemiology of adenoviruses. In: Doerfler W. Adenovirus DNA. Martinus Nujhoff: Boston; 1986.

Wigand R, Adrian T, Bricout F. A new human adenovirus of subgenus D: candidate adenovirus type 42. Arch Virol. 1987;94(3-4):283-6.

Wilgenbusch JC, Swofford D. Inferring evolutionary trees with PAUP*. Curr Protoc Bioinformatics. 2003; Chapter 6:Unit 6.4.

Windheim M, Hilgendorf A, Burgert HG. Immune evasion by adenovirus E3 proteins: exploitation of intracellular trafficking pathways. Curr Top Microbiol Immunol. 2004;273:2985.

WHO Statistical Information System (WHOSIS). Available from: http://who.int/whosis/en/ [2009 Marc 25].

Wu E, Trauger SA, Pache L, Mullen TM, von Seggern DJ, Siuzdak G, Nemerow GR. Membrane cofactor protein is a receptor for adenoviruses associated with epidemic keratoconjunctivitis. J Virol. 2004;78:3897-905.

$\mathrm{Xu}$ W, McDonough MC, Erdman DD. Species-specific identification of human adenoviruses by a multiplex PCR assay. J Clin Microbiol. 2000;38:4114-20.

Young CS. The structure and function of the adenovirus major late promoter. Curr Top Microbiol Immunol. 2003;272:213-49. 
Zhao LY, Liao D. Sequestration of p53 in the cytoplasm by adenovirus type 12 E1B 55kilodalton oncoprotein is required for inhibition of p53-mediated apoptosis. J Virol. 2003;77:13171-81.

Zhang W, Low JA, Christensen JB, Imperiale MJ. Role for the adenovirus IVa2 protein in packaging of viral DNA.J Virol. 2001;75(21):10446-54.

Zhang W, Imperiale MJ. Requirement of the adenovirus IVa2 protein for virus assembly. J Virol. 2003;77(6):3586-94. 
ANEXO 1: Lista de aminoácidos e suas abreviações.

\begin{tabular}{|c|c|c|c|}
\hline Nome & Símbolo & Abreviação & Nomenclatura \\
\hline $\begin{array}{l}\text { Glicina ou } \\
\text { Glicocola }\end{array}$ & Gly, Gli & G & $\begin{array}{l}\text { Ácido 2-aminoacético ou Ácido 2-amino- } \\
\text { etanóico }\end{array}$ \\
\hline Alanina & Ala & A & $\begin{array}{l}\text { Ácido 2-aminopropiônico ou Ácido 2-amino- } \\
\text { propanóico }\end{array}$ \\
\hline Leucina & Leu & $\mathrm{L}$ & $\begin{array}{l}\text { Ácido 2-aminoisocapróico ou Ácido 2-amino-4- } \\
\text { metil-pentanóico }\end{array}$ \\
\hline Valina & Val & $\mathrm{Va}$ & $\begin{array}{l}\text { Ácido 2-aminovalérico ou Ácido 2-amino-3- } \\
\text { metil-butanóico }\end{array}$ \\
\hline Isoleucina & Ile & I & $\begin{array}{l}\text { Ácido 2-amino-3-metil-n-valérico ou ácido 2- } \\
\text { amino-3-metil-pentanóico }\end{array}$ \\
\hline Prolina & Pro & $\mathrm{P}$ & Ácido pirrolidino-2-carboxílíco \\
\hline Fenilalanina & $\begin{array}{l}\text { Phe ou } \\
\text { Fen }\end{array}$ & $\mathrm{F}$ & $\begin{array}{l}\text { Ácido 2-amino-3-fenil-propiônico ou Ácido 2- } \\
\text { amino-3-fenil-propanóico }\end{array}$ \\
\hline Serina & Ser & $\mathrm{S}$ & $\begin{array}{l}\text { Ácido 2-amino-3-hidroxi-propiônico ou Ácido } \\
\text { 2-amino-3-hidroxi-propanóico }\end{array}$ \\
\hline Treonina & Thr, The & $\mathrm{T}$ & Ácido 2-amino-3-hidroxi-n-butírico \\
\hline Cisteina & Cys, Cis & $\mathrm{C}$ & $\begin{array}{l}\text { Ácido 2-bis-(2-amino-propiônico)-3-dissulfeto } \\
\text { ou Ácido 3-tiol-2-amino-propanóico }\end{array}$ \\
\hline Tirosina & Tyr, Tir & Y & $\begin{array}{l}\text { Ácido 2-amino-3-(p-hidroxifenil)propiônico ou } \\
\text { paraidroxifenilalanina }\end{array}$ \\
\hline Asparagina & Asn & $\mathrm{N}$ & Ácido 2-aminossuccionâmico \\
\hline Glutamina & Gln & Q & Ácido 2-aminoglutarâmico \\
\hline $\begin{array}{l}\text { Aspartato ou Ácido } \\
\text { aspártico }\end{array}$ & Asp & $\mathrm{D}$ & $\begin{array}{l}\text { Ácido 2-aminossuccínico ou Ácido 2-amino- } \\
\text { butanodióico }\end{array}$ \\
\hline $\begin{array}{l}\text { Glutamato ou } \\
\text { Ácido glutâmico }\end{array}$ & Glu & $\mathrm{E}$ & Ácido 2-aminoglutárico \\
\hline Arginina & Arg & $\mathrm{R}$ & Ácido 2-amino-4-guanidina-n-valérico \\
\hline Lisina & Lys, Lis & $\mathrm{K}$ & $\begin{array}{l}\text { Ácido 2,6-diaminocapróico ou Ácido 2, 6- } \\
\text { diaminoexanóico }\end{array}$ \\
\hline Histidina & His & $\mathrm{H}$ & Ácido 2-amino-3-imidazolpropiônico \\
\hline Triptofano & Trp, Tri & W & Ácido 2-amino-3-indolpropiônico \\
\hline Metionina & Met & M & Ácido 2-amino-3-metiltio-n-butírico \\
\hline
\end{tabular}

